\title{
Carbon nanotube interaction with extracellular matrix proteins producing scaffolds for tissue engineering
}

This article was published in the following Dove Press journal:

International Journal of Nanomedicine

13 August 2012

Number of times this article has been viewed

\section{Fernanda MP Tonelli' \\ Anderson K Santos' \\ Katia N Gomes ${ }^{2}$ \\ Eudes Lorençon ${ }^{2}$ \\ Silvia Guatimosim ${ }^{3}$ \\ Luiz O Ladeira ${ }^{2}$ \\ Rodrigo R Resende'}

'Cell Signaling and Nanobiotechnology Laboratory, Department of Biochemistry and Immunology, Federal University of Minas Gerais, Belo Horizonte, Brazil; ${ }^{2}$ Nanomaterials Laboratory, Department of Physics, Federal University of Minas Gerais, Belo Horizonte, Brazil; ${ }^{3}$ Intracellular Cardiomiocyte Signaling Laboratory, Department of Physiology and Biophysics, Federal University of Minas Gerais, Belo Horizonte, Brazil

Correspondence: Rodrigo R Resende Cell Signaling and Nanobiotechnology Laboratory, Department of Biochemistry and Immunology, Institute of Biological Sciences, Federal University of Minas Gerais - UFMG, 6627 Av Antônio Carlos, Pampulha, Belo Horizonte, MG 3|270-90|, Brazil

Tel +55 3I 34092627

Email resende@icb.ufmg.br
Abstract: In recent years, significant progress has been made in organ transplantation, surgical reconstruction, and the use of artificial prostheses to treat the loss or failure of an organ or bone tissue. In recent years, considerable attention has been given to carbon nanotubes and collagen composite materials and their applications in the field of tissue engineering due to their minimal foreign-body reactions, an intrinsic antibacterial nature, biocompatibility, biodegradability, and the ability to be molded into various geometries and forms such as porous structures, suitable for cell ingrowth, proliferation, and differentiation. Recently, grafted collagen and some other natural and synthetic polymers with carbon nanotubes have been incorporated to increase the mechanical strength of these composites. Carbon nanotube composites are thus emerging as potential materials for artificial bone and bone regeneration in tissue engineering.

Keywords: carbon nanotubes, tissue engineering, extracellular matrix proteins, collagen, hyaluronic acid, stem cells

\section{Introduction}

Surface structure and related chemistry understanding are vital elements in the design of highly biocompatible materials, since adsorption and adhesion of biological components are involved. These features are even more important in the case of nanostructured materials such as carbon nanotube (CNT) fibers.

The necessity of searching for biocompatible materials that are capable of mimicking the natural extracellular matrix (ECM) and allowing the regeneration of tissues motivated interdisciplinary research on tissue engineering. However, this kind of search isn't new: the Incas used scaffolds made of gold and silver in cranioplasty. ${ }^{1}$

The natural ECM is composed of collagen, proteoglycans, adhesion proteins, and signaling molecules; therefore, a desirable synthetic ECM should resemble as much as possible the natural ECM in order to replace damaged tissue or enable tissue regeneration by providing ideal conditions capable of directing cell behavior identical or as close as possible to natural tissue before injury.

Tissue regeneration occurs due to a series of events conditioned to each other and coordinated by biochemical and biophysical signals involving ECM and the tissue cells. ${ }^{2}$ That is why synthetic, semisynthetic, and natural materials have been tested as organic cell holders capable of not only promoting in an accurate way these signs but also providing a three-dimensional environment, spatially and temporally appropriated for such events to occur; more specifically, an environment capable of inducing correct cellular adhesion and migration, as well as regulating the rate of proliferation, cell growth, and function. For this reason, cell-adhesion mechanisms on CNT monolayer, 
with an aim to designing a novel cell therapeutic device, have been the object of research. ${ }^{3}$

However, despite all the challenges faced since the emergence of tissue engineering, researchers have made great improvements in the area contributing to the development of therapeutic applications. This review aims to revisit topics on nanomaterials and tissue engineering, from the beginnings to future prospects.

\section{A brief history of tissue engineering}

It is considered that the history of tissue engineering starts with Hooke in 1665, when he created the term "cell" and published it in his book Micrographia. ${ }^{4}$ Three years later dates the first evidence of successful study in tissue engineering when grafts were used to repair bones in Amsterdam; 5 however, only 225 years later the concept of "scaffold" was elaborated by Barth: ${ }^{6}$ a porous matrix in which cells can infiltrate to regenerate the injured tissue. Nowadays, this concept has been reformulated to aggregate the idea that a scaffold should be able to determinate the fate of cells, guiding them to promote tissue regeneration. ${ }^{7}$

The cell theory emerged between 1838 and 1839, based on microscopic findings of Schleiden ${ }^{8}$ and Schwann. ${ }^{9}$ But only 20 years later, in 1858 , Virchow ${ }^{10}$ presented the idea that tissue regeneration is dependent on cell proliferation. So was established the relationship between cell proliferation and tissue regeneration.

In 1897, Loeb ${ }^{11}$ envisaged the growth of human cells outside the body, and in 1907 Harrison $^{12}$ was able to promote the growth of frog ectodermal cells in vitro.

In the 1960s, scientists began to achieve success by using metals for the production of inert implants in bone grafting. ${ }^{13}$ In the past 70 years, ceramics and various polymers have also begun to be used. ${ }^{14}$

In 1987, during a National Science Foundation meeting, the term "tissue engineering" was introduced. Tissue engineering was defined as being the application of methods and principles of engineering in life sciences by delimiting a field of multidisciplinary research aimed to develop efficient biological substitutes capable of restoring and/or optimizing normal tissue function. ${ }^{15}$

In 1998, with the development of stem cell lines, these cells have become the foundation of modern tissue engineering. ${ }^{16}$ But before the development of stem cell lines, another important innovation revolutionized tissue engineering: the carbon nanotubes (CNTs). ${ }^{17}$ This class of materials, discovered in 1991 by Sumio Iijima, caused a revolution in the production of biomaterials for tissue regeneration, particularly bone tissue. These CNTs, combined with collagen as biomaterial, are being studied in an attempt to develop nanocomposites to optimize tissue regeneration.

\section{Overview of tissue engineering}

Four components are considered essential for tissue engineering: the ECM, cells, the cytokines on an adequate medium, and a bioreactor. ${ }^{18}$ The scaffold or matrix (ECM) is embedded with living cells in the presence of cytokines able to regulate cell proliferation and differentiation. Then these components are placed into bioreactors that promote ideal conditions for multiplication and for the desirable arrangement of cells on this matrix to be obtained. When the conjugate matrix-cells are deployed within a human body, for example, it is expected that this conjugate will be consistent with the tissue, providing support and leading to desirable cell proliferation. ${ }^{19}$

As cell proliferation and differentiation are occurring, the scaffold slowly biodegrades, gradually allowing the contact of blood vessels and host cytokine with the cells. What was once a matrix-cell conjugate changes, gradually making room for new and desired tissue as regeneration occurs. Following this, the tissue that was being regenerated becomes totally regenerated and starts to work perfectly, as before the lesion. ${ }^{20}$

In order to realize the synthesis of an organic scaffold that is as close as possible to the natural ECM, there must be special care regarding the characteristics that will provide the undifferentiated cells all they need in order to develop; the scaffold must also be biocompatible and biodegradable, with the three-dimensional structure suitable for the promotion of specific tissue regeneration.

\section{What is ECM?}

The extracellular environment is formed by a complex network of biophysical and biochemical signals transmitted to tissue cells by a wide range of factors and mechanisms. This environment that surrounds all cells is essential for the formation and normal function of tissues (homeostasis) and is also essential for the regeneration of these tissues when any damage or pathology takes place. ${ }^{21}$ The ECM is crucial when it comes to movement, growth, adhesion, cell proliferation, and end-cell differentiation; it also influences gene expression and thus phenotype, morphogenesis, cell fate, apoptosis, and various other cellular activities related to training and maintenance of tissue in general. ${ }^{22}$ The geometry of ECM, for example, is essential to modulate cell function and polarity. ${ }^{23}$ 
The ECM is highly hydrated and may have varying degrees of stiffness, depending mainly on the presence and concentration of fibrous protein like collagen, reticular, and elastic fibers. ${ }^{24}$ This rigidity determines not only the mechanical properties of the matrix but also influences the mechanical forces that are transmitted to the tissue's cells and effectively control tissue homeostasis. ${ }^{25}$

ECM also possesses in its composition numerous molecules that perform specific functions on tissues; for example, noncollagenous glycoproteins such as elastin, laminin, and fibronectin, proteoglycans (PGs) with glycosaminoglycan chains, and soluble macromolecules like growth factors, chemokines, and cytokines. ${ }^{26} \mathrm{PGs}$, for example, control tissue's hydration and external compressive forces $;{ }^{27}$ collagen fibers offer resistance to the forces that intend to tighten the tissue, promote cell compaction, ${ }^{28}$ and regulate their own synthesis. Palka and Phang demonstrated that prolidase (an enzyme that plays an important role in the recycling of proline for collagen synthesis and cell growth) activity responds to ECM through signals mediated by the integrin receptor. They have shown that the interaction with type I collagen mediated by the beta-1 integrin receptor regulates cellular prolidase activity in cultured human skin fibroblasts. ${ }^{29}$

\section{ECM influences on cell phenotype and migration}

Howarth and Dourmashkin were the pioneers in describing the effect of ECM geometry on cell function in the 1950s. They reported the appearance of muscle fibers on an agarose overlay. ${ }^{30}$ Later on, in 1983, it was demonstrated ${ }^{23}$ that endothelial cells formed a monolayer on a single surface of a collagen gel substrate, but reorganize into acinar structures when overlaid with a second layer of ECM. ${ }^{23}$

Integrin, another transmembrane protein, in interaction with ECM components can dictate how easy it is to move into the matrix. In fact, ECM stiffness is proportional to the number of integrin-ligand interactions. ${ }^{32}$ The interaction between ECM and fibroblasts also influences the tissue's rigidity. When fibrosis occurs, the stiffness of the matrix dictates to fibroblasts when and how to contract until the repair of the damage area is complete. The fibroblasts' manner and intensity of contraction, along with trophic molecules that exist in the medium, lead to the differentiation into myofibroblasts. ${ }^{33}$

The ECM likewise has an important role in cell migration; this function of ECM, besides being essential during tissue development (morphogenetic process), operates on its homeostasis and regeneration. Cell migration is essential to some processes like cancer metastasis, embryonic development, and wound healing. Migration involves a complex integration of cellular adhesion to the substratum, proteolysis, and remodeling of surrounding ECM; all these processes are regulated by chemical signals such as growth factors. This is a cooperative mechanism that enables the cell to function correctly in the right place. ${ }^{34}$ The ratio of tensile strength of the matrix to the speed of cell migration in the medium is inversely proportional: the lower the degree of resistance of the matrix and the density of members in the molecular medium (ligand densities), the greater the speed with which cells move in the tissue. ${ }^{35}$

Cell movement also takes place according to the gradient of soluble or insoluble signals (chemotaxis) sent to them, and according to the changes between the intercellular contacts. ${ }^{36}$ Cell movement through ECM is also above integrin influence; it plays a role in determining the extent to which the cells contract and the degree of intracellular voltage. That's because integrins support the cells' traction to perform the movement and directs the cells by being part of signaling pathways. ${ }^{32} \mathrm{In}$ order to overcome the resistance imposed by the matrix, the cell can adopt two important strategies: change cell morphology or initiate the ECM's proteolysis. When a cell changes its morphology, it is an adaptation to the extracellular environment in an attempt to reduce resistance on the surface area. In conclusion, these examples illustrate how dynamic is the interaction between cells and matrix. ${ }^{34}$

The 2-D migration is a cyclical phenomenon consisting of several steps: cell polarization, subsequent extension of protrusions in the direction of migration, stabilization of these protrusions, cell contraction, and detachment of the posterior part of the cell. The 3-D migration occurs in a more elaborate way, since the cell needs to overcome the resistance of the biophysical environment. This 3-D migration can occur in two ways: involving (more often) or not involving proteolytic events (moving through the space available on the surface). ${ }^{37}$ During the proteolytic migration, cells make room for their passage through the ECM, producing and activating proteases like cathepsins, serine proteases and matrix metalloproteinases (MMPs), which degrade the protein components of proteoglycans and part of the pericellular matrix. The degradation is very localized and occurs through one of three mechanisms: diffuse proteolysis (executed by proteases released from the cell), intracellular degradation into lysosomes, or degradation by cell surface-associated proteases. ${ }^{38}$

\section{ECM three-dimensionality}

The ECM not only provides support and tensile strength to the cell tissue but also acts as a medium where there 
are three-dimensional substructures for cellular adhesion and handling, storage of growth factors, cytokines, and chemokines, and signaling for morphogenesis and cell differentiation. In general, the biological responses involving multiple interactions between cells and matrix molecules in a three-dimensional way provide a more effective signaling network to promote the development and functioning of body tissues. Three-dimensional matrices have higher efficiency in inducing differentiated cell functions than 2-D substrates. ${ }^{23}$

For this reason, to mimic the natural organic ECM it is essential that the scaffold presents some desirable characteristics related to three dimensions, like high porosity, high surface-volume ratio, high degree of interconnection between the pores of the matrix, appropriate pore size, and an adequate geometry. ${ }^{39}$

\section{Required characteristics for a desirable scaffold and its importance for CNT science}

To qualify a material as scaffold, it must, besides being a porous substrate, possess some essential characteristics regarding performance in body tissues in order to reproduce the natural environment in which the regenerative processes occur. In tissue engineering, biomolecular recognition of synthesized organic support (scaffold) by cells is essential to enhance the volume and surface modification of biomaterials. This recognition can be accomplished through chemical or physical methods, using bioactive molecules such as chains of native ECM proteins and small peptide sequences, which can interact specifically with cellular receptors. ${ }^{40}$

The support must, at first, be made of biocompatible, bioreabsorbable, and biodegradable materials, providing adequate mechanical scaffold necessary to the occurrence of correct interaction between the cells themselves and between the cells and the ECM. For this reason, it must provide: (1) desirable physical and chemical properties for the targeting of specific cells to the ECM, and therefore to the damaged tissue, by promoting the reorganization of the injured tissue in its natural disposition, and (2) organic support needed to rebuild the whole tissue. ${ }^{41}$

The support models must meet a complex hierarchical pattern of cells, including microvascular networks that comprise the stroma and exercise control flow on a microscale, not only in the interstitial space but also among the network of blood vessels and lymphatics. This complex environment has not yet been achieved, but efforts are being made for such an organic model that could be produced satisfactorily. ${ }^{42}$
The synthetic scaffold should act to promote the optimization of growth and cell development in injured tissue. It must be implanted, seeded with cells, directly into the affected area of tissue to be regenerated, ${ }^{43}$ or seeded with cells and cultured in vitro with the intention of forming the new tissue prior to implantation. ${ }^{44}$ Then the entire process of reconstitution occurs, from the successful interaction between cells and cells and ECM, avoiding initiation of an immune response. ${ }^{45}$

One of the most popular materials used in scaffolds for tissue engineering was discovered in 1991 and revolutionized the research field: CNTs. ${ }^{17}$ These nanotubes, since they started being studied, have demonstrated a huge number of interesting characteristics; for example, they have remarkable electrical and mechanical properties and chemical stability. ${ }^{46}$ Nanotubes can, for example, deliver therapeutic molecules and DNA; ${ }^{47-49}$ however, without modifications on their structure, they can induce an immune response. ${ }^{50}$

Nygaard and collaborators demonstrated that in mice, the adjuvant effect of particles on allergic immune responses increases with decreasing particle size and increasing particle surface area, and that CNTs promote allergic responses in mice. ${ }^{45}$ In this way, researchers face the challenge of modifying CNT surface to avoid evoking immune responses and to promote successful regeneration as part of a scaffold.

The first obstacle that researchers had to overcome was the difficulty of manipulating and integrating CNTs with polymers; this is because the CNTs present poor dispersion within a large number of solvents. In fact, they are chemically inert, but through their functionalization it has been possible to solubilize $\mathrm{CNTs}^{51}$ and conjugate them with other substances like collagen. ${ }^{52}$ Added to the CNT, the collagen gel acquires greater resistance consisting of efficient scaffold for growth of cells in three-dimensional arrays. ${ }^{53}$ Nowadays, there are many examples of noncovalent functionalization of CNTs interacting with molecules, such as surfactants, ${ }^{54}$ polymers, ${ }^{55}$ or proteins ${ }^{56}$ in water (often termed "wrapping”). At the same time, this process often induces dispersion of the bundled CNTs in water as a result of the reduction or elimination of their hydrophobicity. Moreover, the debundled single-walled CNTs (SWNTs) are able to retain the conformation of proteins. ${ }^{56}$ A number of reviews have discussed CNT functionalization with many different organic groups and with more detailed information. ${ }^{57-59}$

The dimensions of the CNT become especially relevant to conduct studies on a nanoscale, since its size simulates collagen protein at the nanoscale level. One of the features already fully understood from the ECM is the necessity to 
have in its physical structure a substrate that can interact with fibrous protein, maintaining its integrity for a long time (retarding proteolysis). It is also desirable to allow cells contact with no modification or enhancing of their function. If the goal is to mimic the most natural environment of the ECM to promote tissue-specific regeneration, it is possible to produce nanofibers using electrospinning, which have recently received a lot of attention in order to obtain an adequate support structure for tissue engineering. ${ }^{60}$

The success of this area is now currently in mimicking as accurately as possible the original structure and composition of ECM of several human tissues, in order that they can be regenerated using nontoxic and nonimmunogenic substances capable of leading the most holistic regeneration possible. For that to become reality, researchers continue to seek the broadest possible understanding of interactions of cells among themselves and interactions of cells with the ECM both in vivo and in vitro.

\section{Carbon nanotubes as an alternative to replacement and integration of ECM}

Nanostructured materials arouse interest in the field of bioengineering for the production of "frameworks" called scaffolds, due to their similarities with the ECM present in all parts of the body. Their configurations, dimensions, and physical and chemical properties influence the cellular interactions that lead to the regeneration of tissues, and are seen as a breakthrough in implantable surfaces.

Within the class of nanostructured materials, CNTs have great potential for biomedical applications due to their unique properties, such as low weight, high electrical conductivity, high chemical stability, high thermal conductivity, large surface area, high mechanical strength, and easy incorporation of functional groups to produce scaffolds. The combination of these characteristics makes CNTs a unique material with potential for various applications, including tissue engineering. CNTs can be of two types: single (SWNTs) and multiwalled (MWNTs). ${ }^{61,62}$

SWNTs have diameters ranging from about $0.7 \mathrm{~nm}$ to about $1 \mathrm{~nm}$, but their synthesis with diameters of less than $0.7 \mathrm{~nm}$ using iron nitrate has been reported. ${ }^{63}$ MWNTs have a larger diameter, which can be $4-30 \mathrm{~nm} \cdot{ }^{64,65}$ The lengths of nanotubes can reach sizes up to thousands of times greater, being among cylindrical structures, the highest hardness known. When added to polymers, for example, nanotubes improve the mechanical and electrical properties, making resulting compounds very attractive for biological applications..$^{51,52,66,67}$
SWNTs are also suitable for biomedical imaging. SWNTs with a number of unique intrinsic optical properties have been widely used as contrast agents in Raman imaging, near-infrared fluorescence imaging and photoacoustic imaging in vitro and in vivo. More imaging functionalities including positron emission tomography and magnetic resonance imaging can be achieved by either utilizing external labels or the metal impurities of nanotube samples. Although there is still a long way to go before SWNTs are ready for clinical use, they are promising nanomaterials with great potential in multimodality biomedical imaging. ${ }^{68,69}$

An example of CNTs application is their use in bone-tissue regeneration, in which this nanomaterial has demonstrated biocompatibility with osteoblasts, promoting bone formation..$^{52,70-72}$ This kind of material can also be applied within hyaluronic acid hydrogels to enhance viscoelasticity of biopolymer hydrogels without changing their water-intake capacity. ${ }^{46,67,73}$ Thus this novel hybrid hydrogel can be a suitable material to be used in drug delivery with controlled release, and in tissue engineering. ${ }^{46}$ For an interesting review in which the authors discuss CNTs as carriers for in vitro and in vivo drug delivery in cancer therapy, see Liu et al..$^{74}$

\section{Similarity of nanotubes with ECM}

CNTs have some features that are essential on a scaffold's formation and that are common to natural ECM. For this reason, they may be a great alternative to tissue engineering. One of these characteristics is the high degree of flexibility ${ }^{75}$ and elasticity ${ }^{76}$ that nanotubes have. This high degree of flexibility is directly related to the cohesion of the solid and therefore the covalent chemical bonding of carbon atoms therein. Another common feature between nanotubes and ECM is the presence of porosity of similar diameter. ${ }^{77}$

As mentioned previously, the lower the hardness of the matrix, the greater the speed with which the cells move into the tissue, and therefore the more optimized is cell reconstitution. ${ }^{35}$ SWNTs have pores generally less than $1 \mathrm{~nm}$ in diameter, and the pores of MWNTs vary between 4 and $30 \mathrm{~nm}$ in diameter. ${ }^{65,78}$ The high degree of porosity found in nanotubes makes them very applicable as scaffolds, since the natural ECM is highly porous, and this is a fundamental factor for tissue integration. ${ }^{79}$ Besides the porosity, CNTs also have as large a contact surface area as ECM, another important characteristic. ${ }^{80}$

CNTs may be functionalized with various functional groups and reagents. Several advances have been made in this area, and this phenomenon can make the nanotubes soluble in aqueous and organic solvents, and can modify some 
properties and functions inherent to them. ${ }^{51}$ Functionalized CNTs present improved properties with respect to solubility and dispersion, manipulation, and processibility. The covalent way, either exohedral or endohedral, can be applied to the extremities or sidewall. ${ }^{81}$ It is also possible to decorate CNTs with other nanoparticles, such as silver or gold, ${ }^{82}$ carbohydrate molecules, ${ }^{49,83,84}$ or peptides. ${ }^{85}$ This property makes CNTs efficient when it comes to being as similar as possible to the ECM. It is through the implantation of desirable molecules on the nanotube surface that can promote the interconnection between the numerous pores of the support, in order to obtain a more integrated network.

Another significant property of CNTs is that they can interact with proteins and DNA. In other words, in tissues that are being repaired, a biomolecular interaction occurs between CNTs and macromolecules of ECM before inducing proliferation and cell growth. ${ }^{86,87}$ Also, most desirable for the synthesis of a scaffold, CNTs may be 3-D, like the natural ECM. ${ }^{88,89}$

Besides all these features that make CNTs a highly efficient candidate for tissue-engineering scaffold, they are highly biocompatible according to some studies. ${ }^{47,90}$

In tissue engineering, CNT scaffold becomes a biomaterial increasingly attractive as new biochemistry properties are elucidated; the similarity to ECM allows cultivation of cells on its surface. In 2009, Hirata et al demonstrated that MWNT-coated surface shows strong cell adhesion and an ability to promote protein's assimilation and absorption..$^{91}$

\section{CNTs interact with collagen fibrils and ECM proteins}

CNT scaffolds designed for tissue engineering interact with cells immersed on them, and they are able to do so through such proteins as integrin ${ }^{92}$ and collagen. ${ }^{93}$ The cell-ECM (natural) or cell-CNT scaffold (synthetic) interactions are necessary because cells need to adhere to the matrix in an adequate way to multiply, differentiate, and acquire the correct organization in which they are normally found on the tissue. When a synthetic material is used, all of those cell physiology process occur during scaffold degradation. ${ }^{94}$

Based on the fact that cells possess on their surface receptors for proteins, and that collagen is an abundant protein found in the ECM, it began to be used as a support matrix based on collagen gel adsorbed to CNTs. The use of this combination (collagen CNTs) was only possible through the development of tissue engineering. When the CNTs were embedded in collagen gel, the scientists observed the origin of a tougher material that allowed correct three-dimensional structure of cells: a desirable feature on a biomaterial to be used for tissue regeneration. ${ }^{95}$ Using turbidity as a way of evaluating the interaction between CNTs and collagen molecules, Kuboki et al found that native collagen induced distinct aggregation with CNTs, while denaturation of the protein deprived the molecules of their ability to aggregate with CNTs. It indicates that the rigid 3-D structure of the native collagen triple helix is essential for interaction with CNTs and aggregation. ${ }^{96}$ Nanotube collagen gel is very useful because it resembles the three-dimensional arrangement of the natural ECM beyond being the collagen matrix itself, a biocompatible and biodegradable structure. This sum of features enables the anchorage of cells on scaffold surface, providing stability to allow them to proliferate and begin the desired process of differentiation. Therefore, biodegradation of collagen-based biomaterials for applications such as tissue engineering could potentially lead to the restoration of tissue structure and functionality. ${ }^{97}$ It has become possible to promote the tissue-specific development of seeded cells and the growth of skin, pieces of myocardium, and cellular structures. ${ }^{98}$ It has also been demonstrated that the CNTcollagen biocomposite can induce hydroxyapatite deposition that can be used for bone-fracture regeneration. ${ }^{52}$

CNTs can allow an in vitro simulation of in vivo conditions, making it simple to study or induce in the laboratory natural cellular processes, such as cellular differentiation. In fact, a simple change in nanotube dimension modifies a cell's fate during differentiation..$^{99}$ When fibronectin immobilization on CNT monolayer is done, it leads to an increase in seeding efficiency and on the proliferation rate of stem cells over the scaffold, proving the importance of the interaction between CNTs and ECM proteins on cell metabolism. ${ }^{100}$

Functionalization of CNTs through ECM protein immobilization was successful in producing a biomaterial that can be used in biomedical engineering. ${ }^{3}$ MacDonald et al noted that matrices containing $2-w t \%$ SWNTs showed some delay in the compaction of the gel during the first 3 days of their experiment: an indication that the CNTs improve the mechanical properties of the gel when added to it. ${ }^{52,53}$ It was also noted by Cao et al that the combination collagen/MWNT has really improved mechanical properties compared to pure collagen. This improvement occurs due to the fact that they are, in conjunction, the most optimized three-dimensional arrangement on the nanoscale: allowing greater interaction between cells with the matrix of the injured tissue ${ }^{101}$ (Table 1). 
Table I Applications of CNTs in tissue engineering

\begin{tabular}{|c|c|c|c|}
\hline Cell type & CNT & Function & References \\
\hline $\begin{array}{l}\text { Cells with electrical } \\
\text { activity }\end{array}$ & Carbon nanotube fibers & $\begin{array}{l}\text { Tissue engineering constructs with the capacity to provide } \\
\text { controlled electrical stimulation }\end{array}$ & 175 \\
\hline Neurons & SWNTs & Directly stimulate brain circuit activity & 176 \\
\hline $\begin{array}{l}\text { Epithelial and cardiac } \\
\text { cells }\end{array}$ & Nanotube collagen gel & $\begin{array}{l}\text { Promotes the tissue-specific development of seeded cells and the } \\
\text { growth of skin, pieces of myocardium, and cellular structures }\end{array}$ & 177 \\
\hline Various types & CNTs & $\begin{array}{l}\text { Allow an in vitro simulation of in vivo conditions, making it } \\
\text { simple to study or induce in the laboratory natural cellular } \\
\text { processes such as cellular differentiation }\end{array}$ & 178 \\
\hline Osteoblast & MWNTs & Different osteoblast phenotype depending on 3-D structure & \\
\hline Osteoblast & CNTs & $\begin{array}{l}\text { Roughness of CNT scaffolds was also found to influence the } \\
\text { increase of osteoblastic cell differentiation and proliferation }\end{array}$ & 179 \\
\hline Osteoblast & Vertically aligned $\mathrm{TiO}_{2}$ nanotubes & Accelerated osteoblast cell growth & 180 \\
\hline Hippocampal neurons & $\begin{array}{l}\text { MWNTs coated with 4-hydroxynonenal } \\
\text { on polyethylene amine-layered coverslips }\end{array}$ & Induce neurite outgrowth and cell adhesion & 181 \\
\hline Hippocampal neurons & MWNTs & Synaptic activity increased & 182 \\
\hline Stem cells & MWNTs & Osteoclast differentiation can be inhibited & 183 \\
\hline $\begin{array}{l}\text { Human embryonic } \\
\text { stem cells }\end{array}$ & CNTs grafted with polyacrylic acid & $\begin{array}{l}\text { Stem cells are favorably directed towards } \\
\text { the neural lineage }\end{array}$ & 184 \\
\hline Neural stem cells & Laminin-SWNT films & $\begin{array}{l}\text { Conduct cell differentiation and and their } \\
\text { successful excitation }\end{array}$ & 185 \\
\hline $\begin{array}{l}\text { Mesenchymal stem cells } \\
\text { from adult bone marrow }\end{array}$ & Carbon nanofibers with TGF- $\beta$ & Generation of chondrocytes & 186 \\
\hline
\end{tabular}

Abbreviations: CNTs, carbon nanotubes; SWNTs, single-walled carbon nanotubes; MWNTs, multiwalled carbon nanotubes; TGF, transforming growth factor.

\section{Interaction with osteoblasts, myocytes, cardiomyocytes, and neurons}

One of the main objectives of tissue engineering is developing biocompatible scaffolds that can be used to successfully proliferate osteoblasts, myocytes, and neurons, which can be later grown into full tissues and organs (Figure 1). CNTs have been lauded as a promising material to create the nextgeneration matrix for growing these cells, as current alternatives based on polymers and peptide fibers have failed to show the necessary strength and electrical conductivity. ${ }^{78}$

\section{CNTs and bone cell interaction}

There are many advantages that CNT could claim for providing scaffolds to grow osteoblasts, for example. It is one of the strongest materials on Earth, and has unique mechanical, thermal, and electrical properties, as discussed before, turning it into a flexible, elastic, and low-density material, ideal for incorporation into living tissue. ${ }^{102-105}$

Bone tissue is composed of cells, including osteocytes, osteoblasts, and osteoclasts, and a mineralized ECM enriched with hydroxyapatite crystals. Osteoblasts are the main cells that synthesize bone matrix and are located at bone surface, producing type I collagen, proteoglycans, and glycoproteins, all of them present in the ECM. They are also involved in determining the concentration of calcium phosphates, and take part in matrix mineralization. ${ }^{106-108}$
Studies have been done on the biocompatibility and cellular growth of bone tissues on CNT scaffolds. ${ }^{109,110}$ According to Haddon's group, for example, negatively charged functionalized SWNTs can attract calcium ions, promoting nucleation and crystallization. And surfacecharged CNTs can also inhibit the growth and proliferation of osteoblasts cells, while surface-neutralized ones promote cell growth and the formation of mineralized bone. ${ }^{111,112} \mathrm{It}$ is also widely known that the presence of CNTs in the scaffold promotes cell adhesion. . $^{6,113-115}$

Jell et al performed experiments on polyurethane-CNT nanocomposite (a porous structure) and concluded that the amount of MWNT in the scaffold's structure altered the resulting foam's physical, mechanical, and surface properties, and also the osteoblast phenotype. ${ }^{116}$ The surface roughness of CNT scaffolds was also found to influence the increase of osteoblastic cell differentiation and proliferation. ${ }^{86}$

CNT composites have been shown to have highly textured surfaces; therefore, it is expected for them to influence osteoblast behavior. Furthermore, the rise in roughness might contribute to higher adsorption of fibronectin and vibronectin proteins, increasing the adhesion of cells onto the surface matrices. ${ }^{113,116,117}$

When it comes to osteoclast differentiation, it can be inhibited by MWNTs. Osteoclastic activity is related to the natural resorption of bone tissue, but sometimes can 


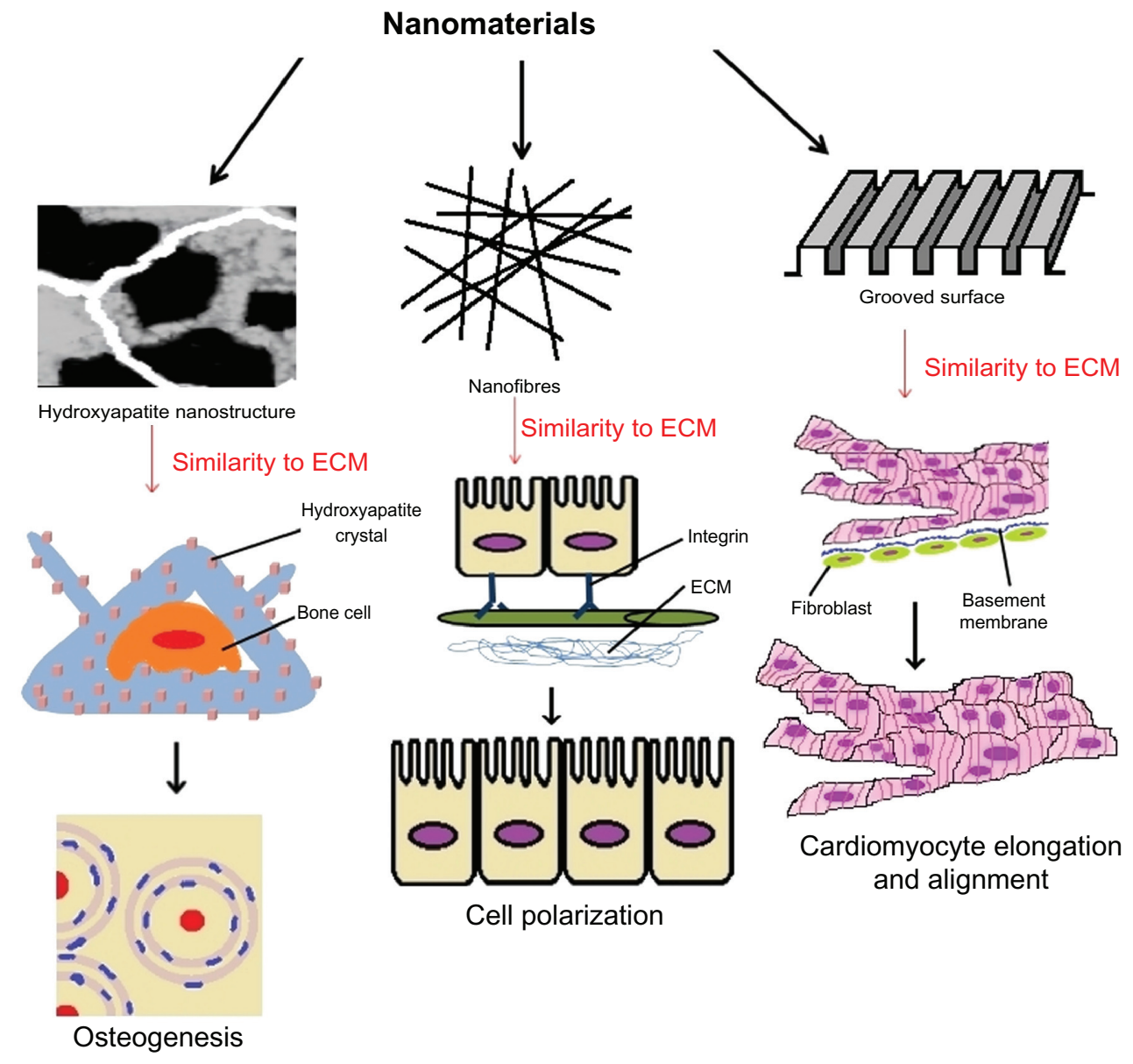

Figure I Carbon nanotubes interacting with different cells for tissue engineering. Abbreviation: ECM, extracellular matrix.

lead to pathological conditions such as osteoporosis and rheumatoid arthritis. MWNTs somehow can cause a decrease on osteoclast number and inhibit ectopic bone resorption in vivo. In vitro, these nanotubes also inhibit osteoclasts and unaffect osteoblasts' growth. ${ }^{118}$

In 2006, Oh et al succeeded in obtaining accelerated osteoblast cell growth on vertically aligned $\mathrm{TiO}_{2}$ nanotubes. The osteoblasts' adhesion and propagation were improved by the topography of the $\mathrm{TiO}_{2}$ nanotubes, and according to the authors, the filopodia of growing cells were going into the nanotube pores, producing an interlocked cell structure. The acceleration in the growth rate of osteoblast cells was $300 \%-400 \%{ }^{119}$

Although most studies focusing on the interaction between bone cells and CNTs are done in vitro, some in vivo studies have also been performed. ${ }^{62,67,71,120,121}$ These studies showed that MWNT implants - often combined with other substances, such as polycarbosilane, chitosan, or hyaluronate - cause no considerable inflammation response and enhance bone-tissue growth. ${ }^{62,67,71,120,121}$ Wilmowsky et al investigated the effects of a $\mathrm{TiO}_{2}$ nanotube structured surface on periimplant bone formation in vivo and compared the results with an untreated standard titanium surface. It was observed that a significantly higher collagen type I expression occurred in the nanostructured implants in comparison to the control group. ${ }^{122}$

Studies have been using the electrospinning process and fibrous matrices to fabricate bone scaffolds with various compositions and 3-D configurations, ${ }^{123,124}$ mainly due to the structural similarity to the tissue ECM, the processing availability of a wide range of materials, and simple setup and operation at low cost. ${ }^{125}$ While electrospinning of purely polymer material systems had already been intensively and routinely researched in the past decade, recent research on the feasibility of incorporating those inorganic nanoparticles, such as $\mathrm{CaCO}_{3}{ }^{126} \mathrm{Fe}_{3} \mathrm{O}_{4},{ }^{127}$ and $\mathrm{CNTs},{ }^{128}$ into fibers to fabricate composite electrospun meshes has made electrospinning very attractive in fulfilling some specific functional applications, especially for bone-tissue engineering. In this way, Shao and collaborators fabricated poly-DL-lactide 
(PLA)/MWNT nanofiber meshes by direct electrospinning of PLA solution containing MWNTs. ${ }^{129}$ These nanofiber meshes maintained the conductive property of MWNTs and offered a unique system to study the synergistic effect of topographic cues and electrical stimulation on osteoblast outgrowth, as a way of exploring their potential application in bone-tissue engineering. Bone regeneration, fracture healing, and more recently stem cell differentiation could be directed with the use of an electric field. ${ }^{130-133}$ The results of unstimulated osteoblast assay showed that the aligned nanofibers as topographic cues could enhance the extension and direct the outgrowth of osteoblasts better than random fibers. In the presence of direct current, the osteoblasts on all samples grew along the electrical current direction. ${ }^{129}$

Cytotoxicity of CNTs on osteoblast and osteoblast-like cultures was also tested by Tutak et al, showing interesting results. It was probably the first work to propose a mechanism for which both cytotoxicity and accelerated bone formation are in some way related. By joining biochemical assays together with total protein counting, cell counting, and electronic microscopy, the authors were able to successfully correlate acute cell death during the first 24 hours after the initial intake of free CNTs in the media. Resulting cell deaths were responsible for the release of growth factors that stimulated the remaining ones to differentiate and secrete ECM proteins. Furthermore, when CNTs were firmly attached to a substrate such as glass, no cytotoxic effects or enhanced growth or differentiation in cells were observed. The introduction of cell lysate into cultures without the presence of CNTs mimicked its effects on total protein assay, producing no reduction in cell viability. ${ }^{134}$

Verdejo et al also evaluated the cytotoxicity of polyurethane CNT foams over osteoblasts. They observed that increasing the CNT loading fraction did not cause cytotoxicity to osteoblasts, nor did it have any detrimental effects on osteoblast differentiation or mineralization. ${ }^{135}$ So considering CNT characteristics when in contact with osteoblasts, Wilmowsky et al and Saito et al considered that CNTs can be useful as an excellent bioactive surface layer for orthopedic and dental applications, for example. ${ }^{105,122}$

\section{CNTs and muscle cell interaction}

There are few studies available in the literature covering the interaction between CNTs and muscle cells. All of them are related to cytotoxicity, and the majority use nonfunctionalized CNTs; however, there are studies like that developed by Raja et al that used functionalized CNTs, and this is exactly the one that showed the greatest impact on cell viability.
The study showed how functionalization or its lack thereof alters significantly nanomaterial biocompatibility and bioresponsiveness. ${ }^{136}$ More studies are necessary in order to show how each variation in CNT nature changes its biological response.

Raja et al used smooth muscle cells with activated carbon or different concentrations of functionalized SWNTs, filtered or not. The results showed that both SWNTs and activated carbon significantly reduced cell number, though the effects of activated carbon were less pronounced. The dose also had an impact on general cell viability: higher concentrations of SWNTs caused lower cell density. ${ }^{136}$

Previous work done by Garibaldi et al used cardiomyocytes to assess nonfunctionalized SWNT cytotoxicity in vitro. Pure SWNTs mixed with medium were incubated with cells for 24,48 , and 72 hours. It was shown that SWNTs bind to the cell membrane, making it hard to detach them by normal washing. The results also showed little toxicity even after 3 days, with the viability and cell number decreasing slightly. After reseeding, changes in cell morphology and a considerable decrease in cell viability were noticed. ${ }^{137}$

Another fascinating study with muscle cells was done by Helfenstein et al. They investigated the effect of ultrafine particles like $\mathrm{TiO}_{2}$ and nanoparticles such as SWNTs in neonatal rat ventricular myocytes. Alterations on impulse conduction velocity and action-potential upstroke velocity were measured, and SWNTs caused the least amount of alteration when compared to untreated control. Also, CNTs did not promote an increase in oxidative stress, nor did they alter myofibrillar structure. ${ }^{138}$ The same results were obtained by Ladeira et al, who used CNTs as siRNA transfection agents. ${ }^{47}$

In 2010, Fung et al concluded that interactions of cultured cardiac myocytes with nanotubes were optimized when CNTs were vertically aligned (so the position is important for interactions to be established). In that position, they were able to penetrate the membrane of neonatal rat ventricular myocytes, while the randomly oriented ones remained external to the cells. ${ }^{139}$

In a study using the electrospinning technique, McKeonFischer and collaborators used coaxially electrospun poly $(\varepsilon-$ caprolactone), acid MWNT, and a hydrogel consisting of polyvinyl alcohol and polyacrylic acid (PCL-MWNT-H) to create a self-contained nanoactuating scaffold for skeletal muscle-tissue replacement. ${ }^{140}$ This nanocomposite was biocompatible, and the acid MWNT increased its conductivity and acted as an inner electrode. Culture myocytes presented a cellular increase, but they also displayed more multinucleated cells with interacting actin filaments, and the addition 
of MWNT also caused the mechanical properties to be greater than those of muscle. ${ }^{140}$

Mu's group have discussed many aspects of carboxylated single-wall (SWNT-COOH) and carboxylated MWNTs (MWNT-COOH). SWNT-COOH was described to inhibit cell proliferation via a nonapoptotic mechanism by suppressing the Smad-dependent bone morphogenetic protein (BMP) signaling pathway and downregulating Id proteins. These events caused cell cycle arrest at $\mathrm{G}_{1} / \mathrm{S}$ transition and inhibited cell proliferation. ${ }^{141} \mathrm{MWNT}-\mathrm{COOH}$ promotes myogenic differentiation of mouse myoblast cells without using any protein or chemical factor, ${ }^{142}$ indicating intrinsic activity of MWNT-COOH. They also demonstrated that MWNT-COOH improved cell survival under the differentiation conditions, inhibiting cell apoptosis by regulating basic helix-loop-helix (bHLH) transcription factors. These effects originated from the binding of MWNT-COOH to BMP receptor 2 (BMPR2), suppressing the BMP signaling pathway and regulating bHLH transcription factors involved in differentiation and apoptosis. ${ }^{142}$

\section{CNT and neuron interaction}

Interactions between CNTs and nerve cells are being heavily investigated in the field of tissue engineering, based on promising possibilities of developing new ways to repair injury. CNTs have been applied in several areas of nerve-tissue engineering to study cell behavior or to instruct the growth and organization of neural networks. CNTs seem to form a perfect pairing with neuron cultures, both of them being able to conduct electrical signals. ${ }^{143}$

Mattson et al were the first to investigate the growth of neurons on MWNTs coated with 4-hydroxynonenal (4-HNE) on polyethylene amine-layered coverslips. They showed that it was able to induce rat embryonic hippocampal neuronal neurite outgrowth and adhesion. ${ }^{144}$ So CNTs are compatible with neuron growth and proliferation, and adsorption of molecules on their surface can lead to the development of selected networks on different matrices.

Lovat et al tried to use nonfunctionalized MWNTs to assess the occurrence of spontaneous postsynaptic currents by single-cell patch-clamp recordings. Hippocampal neurons had their synaptic activity increased by substrate, but their action potential remained the same. ${ }^{145}$

Many other canonical studies have been done, as covered elsewhere, ${ }^{87,109,110}$ including Ni et al, who showed how different groups added to MWNT surface, such as poly $(m-$ aminobenzene sulfonic acid) or ethylenediamine, affect neurite outgrowth and branching. They concluded that more positively charged groups incite greater neurite length and more numerous growth cones. ${ }^{146}$ Gabay et al showed that softlithography techniques could be coupled with CNT growth in order to create nanotopographical surfaces, allowing greater control in cell growth and attachment. Neurons aggregated and accumulated in CNT-coated regions, while the rest of the quartz substrate had very low cell density. ${ }^{147}$ Matsumoto et al demonstrated the use of neurotrophin coating in MWNTs as a biologically active substrate to stimulate neuronal neurite outgrowth. ${ }^{148}$

Also in 2007, Mazzatenta et al developed an integrated SWNT-neuron system to test whether electrical stimulation delivered via SWNT could induce neuronal signaling. To that aim, hippocampal cells were grown on pure SWNT substrates and patch-clamped. The neuronal response was compared to voltage steps delivered either via conductive SWNT substrates or via the patch pipette. The results indicated that SWNTs can directly stimulate brain circuit activity. ${ }^{143}$

A breakthrough study from Fabbro et al developed for the first time an artificial nanomaterials-based scaffold to explore the semichronic (weeks) impact of CNT interfaces on spinal segment growth and activity. ${ }^{149}$ They demonstrated that the long-term impact of an artificial MWNT meshwork characterized by large surface roughness and conductivity ${ }^{150,151}$ favors neurite regrowth in spinal explants, with the appearance of increased growth-cone activity (Figure 2). ${ }^{149}$ Ultimately, this study supports one of the emerging strategies in nanoscale engineering, which is the use of physical features alone to guide different biological responses, without the levels of sophistication required by biomolecule selective patterning. ${ }^{152}$

CNTs have also been shown to favor the differentiation of human embryonic stem cells (hESCs) into neurons. In this study, CNTs were treated to become more hydrophilic and to be later grafted with polyacrylic acid. The resulting polymer was deposited on glass coverslips and dried, being further seeded with hESCs. Results showed that the stem cells were favorably directed towards the neural lineage, with an enhancement double that of poly-L-ornithine - the conventional polymer for growing neurons - and with no decrease in cell viability or adhesion. ${ }^{153}$

Dealing with biocompatibility issues, Bardi et al suggested that the presence of MWNTs might decrease considerably the toxicity of conjugated composites such as Pluronic F127 in vivo. In vitro studies showed that the presence of a higher dose of MWNTs compared to Pluronic F127 decreased cell death. ${ }^{154}$ However, a study conducted by a Swiss group showed acute citotoxicity of SWNTs in primary cultures of chicken embryonic spinal cord and dorsal root ganglia. 


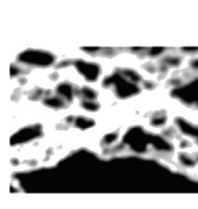

Purified MWCNTs
Culture 1

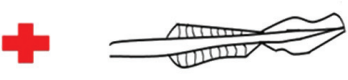

Embryonic spinal cord and dorsal root ganglia thin slices
Culture 2

(control)

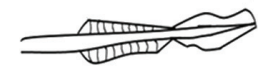

Embryonic spinal cord and dorsal root ganglia thin slices

Immunofluorescence labeling
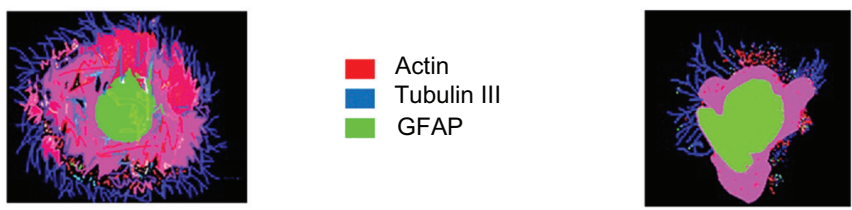

Transmission electronic microscopy and atomic force microscopy

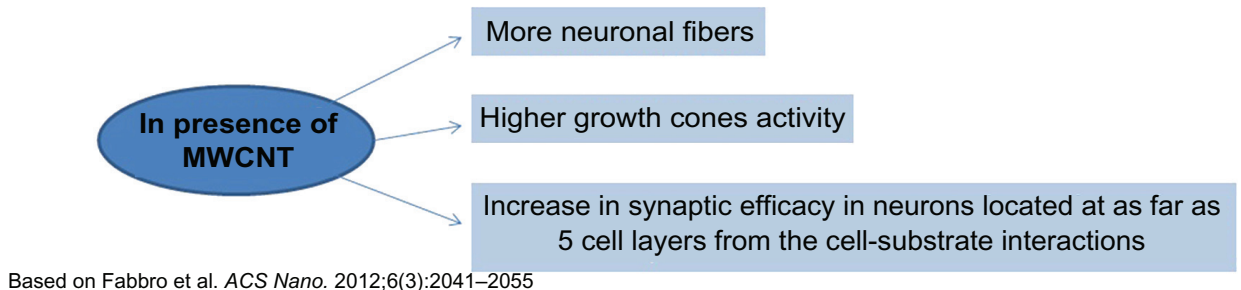

Figure 2 Schematic organotypic spinal slices to model multilayer tissue complexity, interfaced with spinal segments to carbon nanotube scaffolds.

Notes: By immunofluorescence, scanning and transmission electronic microscopy, and atomic force microscopy, nerve fiber growth when neuronal processes exit the spinal explant and develop in direct contact to the substrate was observed, indicating that spinal cord explants interfaced for weeks with purified carbon nanotube scaffolds and grew more neuronal fibers, characterized by different mechanical properties and displaying higher growth-cone activity.

Abbreviations: MWNTs, multiwalled carbon nanotubes; GFAP, glial fibrillary acidic protein.

Glial cells suffered the most, while sensory neurons were mostly affected in dorsal root ganglia-derived cultures. A link was also made between high agglomeration levels of the nanotubes and their increased toxicity and nonfunctionalized SWNTs. The results showed that these agglomerations elicit cytotoxic responses mostly on glial cells. ${ }^{155}$

Malarkey et al's ${ }^{156}$ recent work tackled the issue of how functionalized SWNTs are able to extend the length of neurites while decreasing their numbers. To find an answer, an SWNT polyethylene glycol copolymer was used to treat hippocampal neuronal cultures. They found that the copolymer did not affect the endocytotic loading of a recycling dye in unstimulated cells. However, under stimulating conditions, the initial amount of dye taken up was reduced. SWNT polyethylene glycol affected plasma membrane/vesicular recycling. This effectively means a large surface area, as endocytosis is apparently impaired by the SWNT-PEG, while the reverse movement is not, allowing for a net insertion of plasma membrane.

In 2009, Kam et al focused their attention on trying to overcome one of the key challenges to engineering neural interfaces: minimize the immune response toward implanted electrodes. They fabricated a layer-by-layer structure assembled with SWNTs and laminin. Laminin-SWNT films conducted neural stem cell differentiation and were suitable for their successful excitation. Their results indicate that the protein-SWNT composite can be used as a material foundation of neural electrodes, with chemical structure better adapted with long-term integration with the neural tissue. ${ }^{157}$

Polysaccharide agarose/CNT hybrid materials for applications involving neural tissue engineering and biointerfacing with the nervous system have also been tested. The authors found that agarose/CNT materials are not only conductive and nontoxic, but their functionalization can facilitate cell attachment and response both in vitro and in vivo. ${ }^{158}$

The development of nanomaterial-based interfaces for neuronal networks holds the potential to improve our knowledge on the adhesive interactions that cells and fibers are able to probe and respond to.

\section{Stem cells and CNTs for tissue engineering}

Stem cells are characterized by being unspecialized cells that have the ability to self-renew (proliferate while remaining as stem cells) and differentiate into various cell types. ${ }^{159}$ These 
cells are utilized on tissue engineering and tissue regeneration studies because they possess high proliferation capacity and can acquire diverse cell fates according to the tissue in which they relay. Numerous studies have been done, for example, on using pluripotent cells as precursors to the rebuilding of injured tissues.

Pluripotent cells used in tissue engineering are commonly hematopoietic cells derived primarily from adult peripheral blood (bone marrow). Cells arising from bone marrow can be induced to differentiate into adipocytes, osteoblasts, neural, myocytes, or chondrocytes, and are great candidates for rebuilding tissues. These stem cells can be directly injected into the injured tissue, or grown on tissue culture flasks beforehand, be conjugated with the previously established scaffold, then used to regenerate the lesion, and can even be used as part of the forming scaffold for therapeutic purposes (Figure 3). ${ }^{160}$

Mesenchymal stem cells, which are pluripotent cells, can theoretically perform the entire process of cell reconstitution.
They can multiply and originate various other cell types, thus regenerating the local tissue that has suffered damage. After and during the differentiation process of pluripotent cells into specific cell types, they will start to produce different compounds needed for the maintenance of the neoformed tissue and the occurrence of angiogenesis. These events are mediated by molecules like growth factors and proteins related to cell multiplication and differentiation (Figure 3). ${ }^{161}$

The whole differentiation of pluripotent stem cells into cells of a specific tissue will be led by the environment that surrounds them. In the case of regeneration using CNTs and stem cells, the scaffold of biomaterial will dictate the cells' fate. For this reason, the microenvironment surrounding the stem cells must have the nanoscale morphology and components capable of making them commit to the specific cell fate. Scaffolds must acquire the topological and morphological features of the stem cells' niche, allowing them to differentiate into the desired cell fate. ${ }^{162}$ That is why efforts to develop scaffolds with functions and properties capable of mimicking

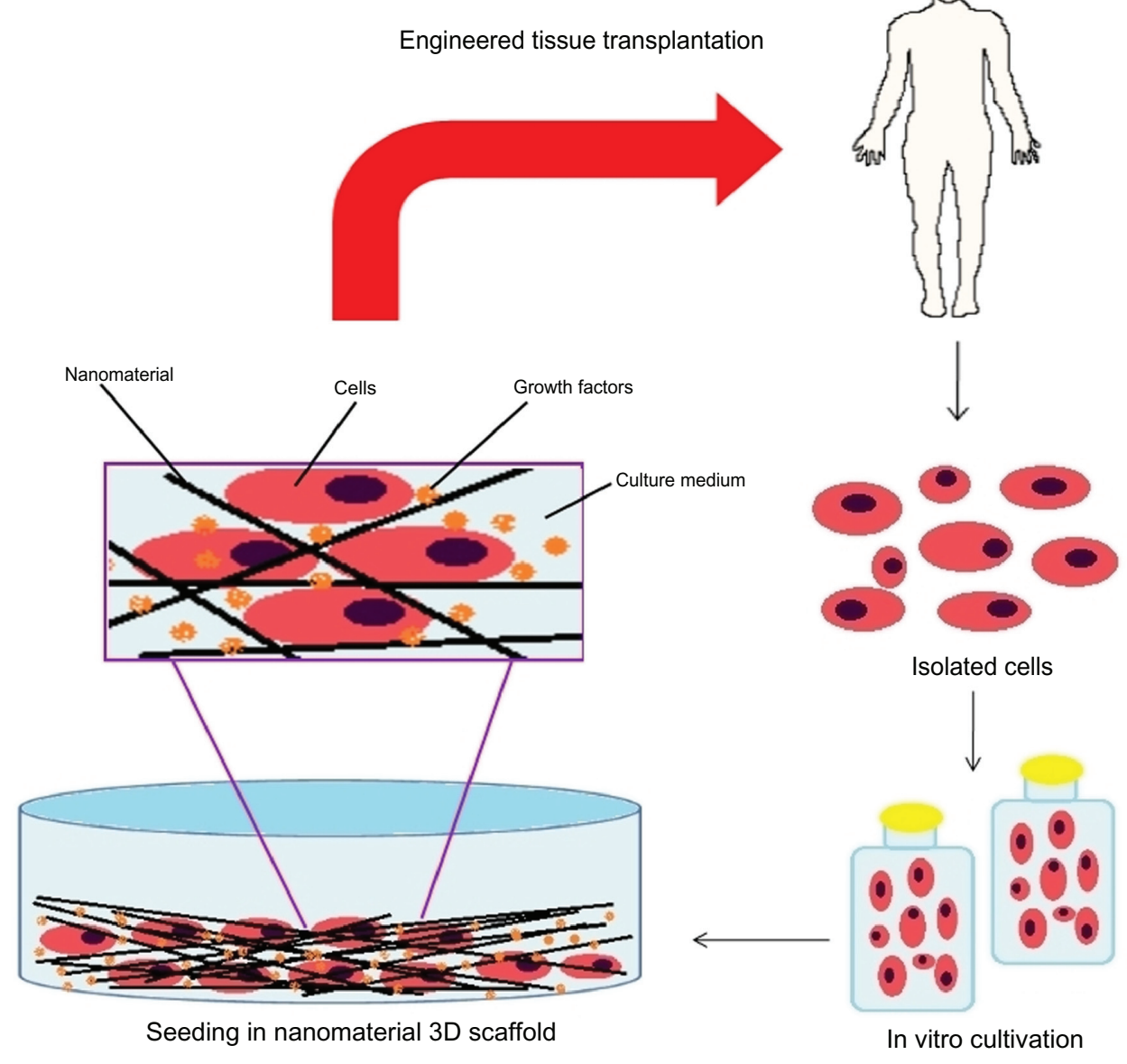

Figure 3 Representative scheme for tissue repair using stem cells. 
the natural ECM on the same scale are essential to reconstruct lesioned tissues. ${ }^{163}$ Although various one-dimensional structures have been utilized for simulating stem cell niches, they were larger than tens of nanometers and thus might cause some disturbance to surrounding biosystems under in vivo environments. On the other hand, CNTs have drawn attention for stem cell engineering, ${ }^{52,164-166}$ and were expected to generate minimum disturbance to the surrounding biosystems due to the small diameter of CNTs. It was also observed that the adhesion, growth, and differentiation of stem cells on CNT matrices were increased. ${ }^{167}$ For this purpose, it was necessary to know if hMSCs could recognize individual CNTs in CNT networks. Namgung's group found that it is possible, and furthermore the alignment of the individual CNTs can affect the growth and differentiation of the hMSCs. The hMSCs on the aligned CNT networks were stretched along the alignment direction of the individual CNTs in the networks. They also observed the enhanced proliferation and osteogenic differentiation of the hMSCs on the aligned CNT networks, and that the osteogenic differentiation could be related to the upregulation of genes involved in the mechanotransduction pathways in the hMSCs. ${ }^{166}$

Li et al in 2005 used mesenchymal stem cells from adult bone marrow, which are undifferentiated and multipotent, for the generation of chondrocytes cultured on a threedimensional nanofiber scaffold, treated with a family of growth factors (transforming growth factor beta). They concluded that this scaffold was a possible candidate for tissue engineering aimed at cartilage repair, since using this it was possible to achieve an efficient formation of cartilaginous tissue, through regeneration performed by stem cells after the scaffold's degradation. ${ }^{168}$

Siddappa et al proved in 2008 that bone formation was possible even in vivo using hMSCs. They demonstrated for the first time that bone formation by hMSCs can be significantly augmented through manipulation of the in vitro signal transduction by using a simple compound like cyclic adenosine monophosphate. Activation of protein kinase A elicits an immediate response inducing the expression of some genes like ID2 and $F o s B$, and induces the secretion of bone-related cytokines (BMP-2, insulin-like growth factor 1, interleukin 11), leading to robust in vivo bone formation through hMSCs. The enormous plasticity of hMSCs has also been established. ${ }^{169}$

\section{Stem cells and carbon nanotubes - a new tissue}

The generation of synthetic ECMs that are able to exert control over the process of stem cell differentiation is desirable.
When a scaffold is produced and seeded with stem cells, it is known that the whole process of tissue formation and homeostasis of tissue repair, as well as degree of regeneration, is dependent on the fidelity of the differentiation process adopted by these cells. ${ }^{170,171}$

As this process involves a very wide range of signals and metabolic pathways, it is highly dependent on the ECM and therefore dependent on scaffold structure. There are still several technical hurdles that need to be overcome in order to enable stem cells to be used in humans for the regeneration of damaged tissues without risk to human health, such as loss of control over the process of cell proliferation and differentiation, which can lead to cancer generation. Signals from the environment can, for example, instead of stimulating the onset of a cellular differentiation, induce the process of cell division in order to self-renew the pool of undifferentiated cells. ${ }^{172}$

Both processes - cell proliferation and differentiation are based mainly on the right nanotopography surroundings and cellular microenvironment composition, and on the presence of appropriate substrates.

According to $\mathrm{Oh}$ et al, by changing the dimensions of the nanotubular scaffold, it is possible to increase adhesion of hMSCs and also allows the promotion of their specific differentiation into the osteoblast. They demonstrated that a narrow range of CNT dimensions led to a dramatic change in hMSC behavior. ${ }^{99}$

Bioactive materials remain to be developed for a specific objective: dictate to stem cells the correct and highly specific fate. Lutolf and Hubbell affirm that a scaffold with MMPs or plasmin, an integrin-binding adhesion ligand, and the boneinducing growth factor BMP-2 is a matrix capable of promoting bone remodeling when implanted in fractured bones. ${ }^{21}$

\section{Recent nanomaterial applications and future prospects}

One possible application of CNTs and the main focus of this review is the development of scaffolds for safe and efficient tissue engineering. The desirable objective is the creation of functional 3-D tissues using cells (for example, stem cells) combined with scaffolds (for example, CNTs with ECM proteins) or devices (like neuron sensors) that can facilitate cell growth, organization, and differentiation. Scientists want to elucidate successful clinical therapies for replacing human heart, liver, cartilage, bone, and other tissues. If this becomes possible and secure, the need for organ transplants will decrease because tissue regeneration would be a reality ${ }^{173}$ (Figure 4).

Another important use of CNTs relies on its electronic property, which can be used to dictate cell differentiation. The 
Carbon nanotubes

(CNTs can be functionalizated and

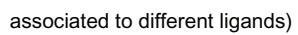

Scaffold

(CNTs increase the strength
Cells

(Stem cells or cells that have this kind of ECM 3D structure)
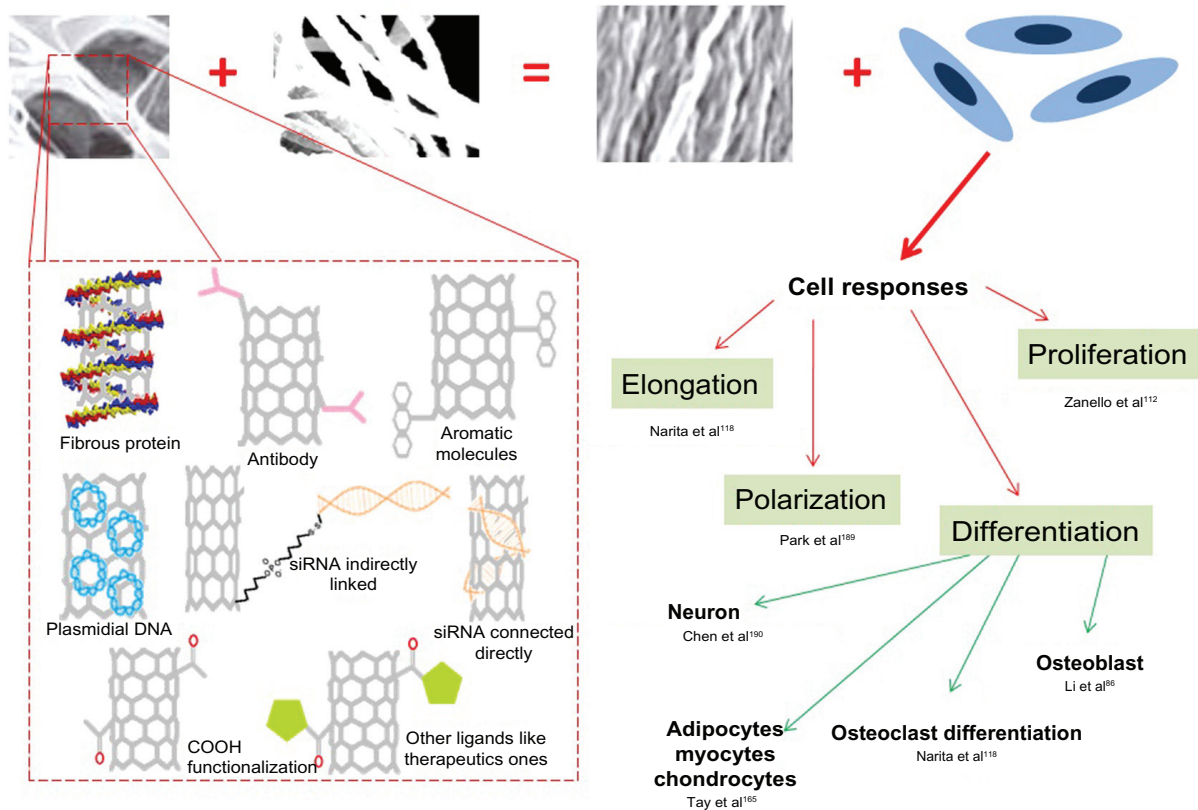

Figure 4 Composites of carbon nanotubes and collagen can resemble extracellular matrix, leading to diverse cell response, which can be directed according to carbon nanotube functionalization. (C) 2009, Springer. Adapted with kind permission from Springer Science and Business Media: Silva EE, Colleta HHMD, Ferlauto AS, et al. Nanostructured 3-D collagen/nanotube biocomposites for future bone regeneration scaffolds. Nano Res. 2009;2:462-473.52

Abbreviations: CNTs, carbon nanotubes; ECM, extracellular matrix.

unique structure, topology, dimensions, and other physical and chemical characteristics of CNTs make them a material that can be considered the most perfect fiber that has ever been fabricated. Scientists have also demonstrated that CNTs can be used to create powerful pressure sensors ${ }^{174}$ or long-life rechargeable batteries. ${ }^{175}$

CNTs can also be used as drug/vaccine-delivery vehicles, but uses related to humans are still under research. Caution when handling CNTs is necessary, because cytotoxity assays can be controversial when it comes to uses in vivo..$^{90}$

\section{Acknowledgments}

Resende, Ladeira, and Guatimosim are grateful for grant support from Fundação de Amparo à Pesquisa do Estado de Minas Gerais, Conselho Nacional de Desenvolvimento Científico e Tecnológico, Programa de Apoio a Núcleos de Excelência (APQ-04334-10), and Capes. Brazil. We would like to thank Professor Christopher Kushmerick for English correction.

\section{Disclosure}

The authors report no conflicts of interest in this work.

\section{References}

1. Chim H, Schantz JT. New frontiers in calvarial reconstruction: integrating computer-assited design ans tissue engineering in cranioplasty. Plast Reconstr Surg. 2005;116(6):1726-1741.

2. Hechavarria D, Dewilde A, Braunhut S, Levin M, Kaplan DK. BioDome regenerative sleeve for biochemical and biophysical stimulation of tissue regeneration. Med Eng Phys. 2010;32(9):1065-1073.

3. Cai N, Wong CC, Gong YX, Tan SCW, Chan V, Liao K. Modulating cell adhesion dynamics on carbon nanotube monolayer engineered with extracellular matrix proteins. ACS Appl Mater Interfaces. 2010;2(4):1038-1047.

4. Hooke R. Micrographia: Or Some Physiological Descriptions of Minute Bodies Made by Magnifying Glasses with Observations and Inquiries Thereupon. London: Royal Society; 1665.

5. Kroeze RJ, Helder MN, Govaert LE, Smit TH. Biodegradable polymers in bone tissue engineering. Materials. 2009;2:833-856.

6. Barth A. Ueber histologische befunde nach knochenimplantationen. Arch Klin Chir. 1893;46:409-417.

7. Gloria A, Russo T, De Santis R, Ambrosio L. 3D fiber deposition technique to make multifunctional and tailor-made scaffolds for tissue engineering applications. J Appl Biomater Biomech. 2009;7(3): $141-152$.

8. Schleiden MJ. Beiträge zur phytogenesis. Archiv für Anatomie, Physiologie und wissenschaftliche Medicin. 1838:137-176.

9. Schwann T. Mikroskopische Untersuchungen über die Übereinstimmung in der Struktur und dem Wachsthum der Thiere und Pflanzen. Berlin: Verlag der Sander'schen Buchhandlung; 1839.

10. Virchow R. Die Cellular-Pathologie in ihrer Begründung auf physiologische und pathologische Gewebelehre. Berlin: A Hirschwald; 1858.

11. Loeb L. Uber die Entstehung von Bindegewebe, Leukocyten und roten Blutkorperchen aus Epithel und uber eine Methode, isolierte Gewebsteile zu zuchten. Stern; 1897. 
12. Harrison RG. Observations on the living developing nerve fiber. Proc Soc Exp Biol Med. 1907;4:140-143.

13. Sieber HP, Rieker CB, Köttig P. Analysis of 118 second-generation metalon-metal retrieved hip implants. J Bone Joint Surg. 1999;81(1): 46-50.

14. Benum P, Lyng S, Bo O, Rafn I, Haffner JFW. Porous ceramics as a bone substitute in the mediale condyle of the tibia. Acta Orthop Scand. 1976;47:158-166.

15. Bell E, Ehrlich HP, Buttle DJ, Nakatsuji T. Living tissue formed in vitro and accepted as skin-equivalent tissue of full thickness. Science. 1981;211(4486):1052-1054.

16. Amit M, Carpenter MK, Inokuma MS, et al. Clonally derived human embryonic stem cell lines maintain pluripotency and proliferative potential for prolonged periods of culture. Dev Biol. 2000;227(2):271-278.

17. Iijima S. Helical microtubules of graphitic carbon. Nature. 1991; 354:56-58.

18. Sikavitsas VI, Bancroft GN, Mikos AG. Formation of three-dimensional cell/polymer constructs for bone tissue engineering in a spinner flask and a rotating wall vessel bioreactor. J Biomed Mater Res. 2002; 62(1):136-148.

19. Qiu QQ, Ducheyne P, Ayyaswamy PS. Fabrication, characterization and evaluation of bioceramic hollow microspheres used as microcarriers for 3-D bone tissue formation in rotating bioreactors. Biomaterials. 1999;20(11):989-1001.

20. Kasper C, Suck K, Anton F, Scheper T, Kall S, van Griensven M. A newly developed rotating bed bioreactor for bone tissue engineering. In: Ashammakhi N, Reis R, Chiellini E, editors. Topics in Tissue Engineering. Vol 3. Oulu: Biomaterials and Tissue Engineering Group; 2007.

21. Lutolf MP, Hubbell JA. Synthetic biomaterials as instructive extracellular microenvironments for morphogenesis in tissue engineering. Nat Biotechnol. 2005;23(1):47-55.

22. De Arcangelis A, Georges-Labouesse E. Integrin and ECM functions: roles in vertebrate development. Trends Genet. 2000;16(9):389-395.

23. Montesano R, Mouron P, Amherdt M, Orci L. Collagen matrix promotes reorganization of pancreatic endocrine cell monolayer into islet-like organoids. J Cell Biol. 1983;97:935-939.

24. Steinberg MS. "ECM": its nature, origin and function in cell aggregation. Exp Cell Res. 1963;30(2):257-279.

25. Frantz C, Stewart KM, Weaver VM. The extracellular matrix at a glance. J Cell Sci. 2010;123:4195-4200.

26. Pizzo AM, Kokini K, Vaughn LC, Waisner BZ, Voytik-Harbin SL. Extracellular matrix (ECM) microstructural composition regulates local cell-ECM biomechanics and fundamental fibroblast behavior: a multidimensional perspective. J Appl Physiol. 2005;98(5): 1909-1921.

27. Han E, Chen SS, Klisch SM, Sah RL. Contribution of proteoglycan osmotic swelling pressure to the compressive properties of articular cartilage. Biophys J. 2011;101(4):916-924.

28. Bourke JE, Li X, Foster SR, et al. Collagen remodelling by airway smooth muscle is resistant to steroids and $\beta 2$-agonists. Eur Respir $J$. 2011;37(1):173-182.

29. Palka JA, Phang JM. Prolidase activity in fibroblasts is regulated by interaction of extracellular matrix with cell surface integrin receptors. J Cell Biochem. 1997;67(2):166-175.

30. Howarth S, Dourmashkin R. A technique for the study of myogenesis in vitro. Exp Cell Res. 1958;15(3):613-615.

31. Montesano R, Mouron P, Amherdt M, Orci L. Collagen matrix promotes reorganization of pancreatic endocrine cell monolayer into islet-like organoids. J Cell Biol. 1983;97:935-939.

32. Vicente-Manzanares M, Choi CK, Horwitz AR. Integrins in cell migration-the actin connection. J Cell Sci. 2009;122(2):199-206.

33. John J, Quinlan AT, Silvestri C, Billiar K. Boundary stiffness regulates fibroblast behavior in collagen gels. Ann Biomed Eng. 2010;38(3): 658-673.

34. Gobin AS, West JL. Cell migration through defined, synthetic ECM analogs. FASEB J. 2002;16:751-753.
35. Bauer AL, Jackson TL, Jiang Y. Topography of extracellular matrix mediates vascular morphogenesis and migration speeds in angiogenesis. PLoS Comput Biol. 2009;5(7):127-133.

36. Franca-Koh J, Devreotes PN. Moving forward: mechanisms of chemoattractant gradient sensing. Physiology. 2004;19(5):300-308.

37. Yamaguchi H, Wyckoff J, Condeelis J. Cell migration in tumors. Curr Opin Cell Biol. 2005;17(5):559-564.

38. Wolf K, Friedl P. Extracellular matrix determinants of proteolytic and nonproteolytic cell migration. Trends Cell Biol. 2011;21(12): 736-744.

39. Tiainen H, Lyngstadaas SP, Ellingsen JE, Haugen HJ. Ultra-porous titanium oxide scaffold with high compressive strength. J Mater Sci Mater Med. 2010;21(10):2783-2792.

40. Spector M. Novel cell-scaffold interactions encountered in tissue engineering: contractile behavior of musculoskeletal connective tissue cells. Tissue Eng. 2002;8(3):351-357.

41. Xie XH, Wang XL, Zhang G, et al. Structural and degradation characteristics of an innovative porous PLGA/TCP scaffold incorporated with bioactive molecular icaritin. Biomed Mater. 2010;5:1-10.

42. Truslow JG, Price GM, Tien J. Computational design of drainage systems for vascularized scaffolds. Biomaterials. 2009;30(26): 4435-4443.

43. Bueno EM, Laevsky G, Barabino GA. Enhancing cell seeding of scaffolds in tissue engineering through manipulation of hydrodynamic parameters. J Biotechnol. 2007;129(3):516-531.

44. Lee CR, Grodzinsky AJ, Hsu HP, Spector M. Effects of a cultured autologous chondrocyte-seeded type II collagen scaffold on the healing of a chondral defect in a canine model. J Orthop Res. 2003;21(2): 272-281.

45. Nygaard UC, Hansen JS, Samuelsen M, Alberg T, Marioara CD, Løvik M. Single-walled and multi-walled carbon nanotubes promote allergic immune responses in mice. Toxicol Sci. 2009;109(1):113-123.

46. Bhattacharyya S, Guillot S, Dabboue H, Tranchant JF, Salvetat JP. Carbon nanotubes as structural nanofibers for hyaluronic acid hydrogel scaffolds. Biomacromolecules. 2008;9:505-509.

47. Ladeira MS, Andrade VA, Gomes ERM, et al. Highly efficient siRNA delivery system into human and murine cells using single-wall carbon nanotubes. Nanotechnology. 2010;21(38):101-113.

48. de Menezes VM, Michelon E, Rossato J, Zanella I, Fagan SB. Carbon nanostructures interacting with vitamins $\mathrm{A}, \mathrm{B} 3$ and $\mathrm{C}$ : $\mathrm{ab}$ initio simulations. J Biomed Nanotechnol. 2012;8(2):345-349.

49. Madani SY, Tan A, Dwek M, Seifalian AM. Functionalization of single-walled carbon nanotubes and their binding to cancer cells. Int $J$ Nanomedicine. 2012;7:905-914.

50. Elhissi AMA, Ahmed W, Hassan IU, Dhanak VR, D'Emanuele A. Carbon nanotubes in cancer therapy and drug delivery. J Drug Deliv. 2012;2012:1-10.

51. Sun YP, Fu K, Lin Y, Huang W. Functionalized carbon nanotubes: properties and applications. Acc Chem Res. 2002;35(12): 1096-1104.

52. Silva EE, Colleta HHMD, Ferlauto AS, et al. Nanostructured 3-D collagen/nanotube biocomposites for future bone regeneration scaffolds. Nano Res. 2009;2:462-473.

53. MacDonald RA, Laurenzi BF, Viswanathan G, Ajayan PM, Stegemann JP. Collagen-carbon nanotube composite materials as scaffolds in tissue engineering. J Biomed Mater Res A. 2005;74(3):489-496.

54. Shin JY, Premkumar T, Geckeler KE. Dispersion of single-walled carbon nanotubes by using surfactants: are the type and concentration important? Chemistry. 2008;14(20):6044-6048.

55. Kim JB, Premkumar T, Giani O, Robin JJ, Schue F, Geckeler KE. A mechanochemical approach to nanocomposites using single-wall carbon nanotubes and poly(L-lysine). Macromol Rapid Commun. 2007;28(6):767-771.

56. Nepal D, Geckeler KE. Proteins and carbon nanotubes: close encounter in water. Small. 2007;3(7):1259-1265.

57. Lee Y, Geckeler KE. Carbon nanotubes in the biological interphase: the relevance of noncovalence. Adv Mater. 2010;22(36):4076-4083. 
58. Byrne MT, Gun'ko YK. Recent advances in research on carbon nanotube-polymer composites. Adv Mater. 2010;22(15):1672-1688.

59. Liu Z, Tabakman S, Welsher K, Dai HJ. Carbon nanotubes in biology and medicine: in vitro and in vivo detection, imaging and drug delivery. Nano Res. 2009;2(2):85-120.

60. Thomas V, Dean DR, Jose MV, Mathew B, Chowdhury S, Vohra YK. Nanostructured biocomposite scaffolds based on collagen coelectrospun with nanohydroxyapatite. Biomacromolecules. 2007;8:631-637.

61. Harrison BS, Atala A. Carbon nanotube applications for tissue engineering. Biomaterials. 2007;28(2):344-353.

62. Abarrategi A, Gutierrez MC, Moreno-Vicente C, et al. Multiwall carbon nanotube scaffolds for tissue engineering purposes. Biomaterials. 2008; 29(1):94-102.

63. Arjmandi N, Sasanpour P, Rashidian B. CVD synthesis of smalldiameter single-walled carbon nanotubes on silicon. Comput Sci Eng Electr Eng. 2009;16(1):61-64.

64. Holt JK, Park HG, Wang Y, et al. Fast mass transport through sub-2nanometer carbon nanotubes. Science. 2006;312(5776):1034-1037.

65. Ferlauto A, de Florio DZ, Fonseca FC, Muccillo R, Traversa E, Ladeira LO. Chemical vapor deposition of multi-walled carbon nanotubes from nickel/yttria-stabilized zirconia catalysts. Appl Phys A Mater Sci Process. 2006;84:271-276.

66. Ajayan PM. Nanotubes from carbon. Chem Rev. 1999;99:1787-1799.

67. Mendes RM, Silva GA, Caliari MV, Silva EE, Ladeira LO, Ferreira AJ. Effects of single wall carbon nanotubes and its functionalization with sodium hyaluronate on bone repair. Life Sci. 2010;87(7-8): 215-222.

68. Liu ZA, Yang K, Lee ST. Single-walled carbon nanotubes in biomedical imaging. J Mater Chem. 2011;21(3):586-598.

69. Welsher K, Liu Z, Sherlock SP, et al. A route to brightly fluorescent carbon nanotubes for near-infrared imaging in mice. Nat Nanotechnol. 2009;4(11):773-780.

70. Singh MK, Gracio J, LeDuc P, et al. Integrated biomimetic carbon nanotube composites for in vivo systems. Nanoscale. 2010;2(12): 2855-2863.

71. Usui Y, Aoki K, Narita N, et al. Carbon nanotubes with high bone-tissue compatibility and bone-formation acceleration effects. Small. 2008;4(2): 240-246.

72. Khang D, Sato M, Price RL, Ribbe AE, Webster TJ. Selective adhesion and mineral deposition by osteoblasts on carbon nanofiber patterns. Int J Nanomedicine. 2006;1(1):65-72.

73. Pelto J, Haimi S, Puukilainen E, et al. Electroactivity and biocompatibility of polypyrrole-hyaluronic acid multi-walled carbon nanotube composite. J Biomed Mater Res A. 2010;93(3):1056-1067.

74. Liu Z, Robinson JT, Tabakman SM, Yang K, Dai HJ. Carbon materials for drug delivery and cancer therapy. Mater Today. 2011;14(7-8): 316-323.

75. Riaz M, Fulati A, Amin G, Alvi NH, Nur O, Willander M. Buckling and elastic stability of vertical $\mathrm{ZnO}$ nanotubes and nanorods. J Appl Phys. 2009;106:121-127.

76. Wong EW, Sheeran PE, Lieber CM. Nanobeam mechanics: elasticity, strength and toughness of nanorods and nanotubes. Science. 1997;277:1971-1975.

77. Esteves IAAC, Cruz FJAL, Müller EA, Agnihotri S, Mota JPB. Determination of the surface area and porosity of carbon nanotube bundles from a Langmuirian analysis of sub- and supercritical adsorption data. Carbon. 2009;47(4):948-956.

78. Jagtoyen M, Pardue J, Rantell T, Derbyshire F. Porosity of carbon nanotubes. Adsorpt Sci and Technol. 2000;17:289-293.

79. Shokrgozar MA, Mottaghitalab F, Mottaghitalab V, Farokhi M. Fabrication of porous chitosan/poly(vinyl alcohol) reinforced singlewalled carbon nanotube nanocomposites for neural tissue engineering. J Biomed Nanotechnol. 2011;7(2):276-284.

80. Raymundo-Piñero E, Cazorla-Amorós D, Linares-Solano A, et al. High surface area carbon nanotubes prepared by chemical activation. Carbon. 2002;40:1597-1617.
81. Hirsch A, Vostrowsky O. Functionalization of carbon nanotubes. Top Curr Chem. 2005;245:193-237.

82. Lorençon E, Ferlauto AS, de Oliveira S, et al. Direct production of carbon nanotubes/metal nanoparticles hybrids from a redox reaction between metal ions and reduced carbon nanotubes. ACS Appl Mater Interfaces. 2009;1(10):2104-2106.

83. Lorençon E, Lacerda RG, Ladeira LO, et al. Thermal behavior of carbon nanotubes decorated with gold nanoparticles. J Therm Anal Calorim. 2011;105:953-959.

84. Jain AK, Dubey V, Mehra NK, et al. Carbohydrate-conjugated multiwalled carbon nanotubes: development and characterization. Nanomedicine. 2009;5(4):432-442.

85. Villa CH, Dao T, Ahearn I, et al. Single-walled carbon nanotubes deliver peptide antigen into dendritic cells and enhance IgG responses to tumor-associated antigens. ACS Nano. 2011;5(7): 5300-5311.

86. Li X, Liu H, Niu X, et al. The use of carbon nanotubes to induce osteogenic differentiation of human adipose-derived MSCs in vitro and ectopic bone formation in vivo. Biomaterials. 2012;33(19): 4818-4827.

87. Hu H, Ni Y, Montana V, Haddon RC, Parpura V. Chemically functionalized carbon nanotubes as substrates for neuronal growth. Nano Lett. 2004;4(3):507-511.

88. Shin SR, Bae H, Cha JM, et al. Carbon nanotube reinforced hybrid microgels as scaffold materials for cell encapsulation. ACS Nano. 2012;6(1):362-372.

89. Hirata E, Uo M, Nodasaka Y, et al. 3D collagen scaffolds coated with multiwalled carbon nanotubes - initial cell attachment to internal surface. J Biomed Mater Res. 2010;93(B):544-550.

90. Smart SK, Cassady AI, Lu GQ, Martin DJ. The biocompatibility of carbon nanotubes. Carbon. 2006;44(6):1034-1047.

91. Hirata E, Uo M, Takita H, Akasaka T, Watari F, Yokoyama A. Development of a 3D collagen scaffold coated with multiwalled carbon nanotubes. J Biomed Mater Res. 2008;90(2):629-634.

92. Lahiri D, Benaduce AP, Kos L, Agarwal A. Quantification of carbon nanotube induced adhesion of osteoblast onhydroxyapatite using nano-scratch technique. Nanotechnology. 2011;22:22-31.

93. Cellot G, Toma FM, Varley ZK, et al. Carbon nanotube scaffolds tune synaptic strength in cultured neural circuits: novel frontiers in nanomaterial-tissue interactions. J Neurosci. 2011;31(36): 12945-12953.

94. Yang Y, Becker ML, Bolikal D, Kohn J, Zeiger DN, Simon CG Jr. Combinatorial polymer scaffold libraries for screening cell-biomaterial interactions in 3-D. Adv Mater. 2008;20:1-7.

95. Tosun Z, McFetridge PS. A composite SWNT-collagen matrix: characterization and preliminary assessment as a conductive peripheral nerve regeneration matrix. J Neural Eng. 2010;7:31-41.

96. Kuboki Y, Terada M, Kitagawa Y, Abe S, Uo M, Watari F. Interaction of collagen triple-helix with carbon nanotubes: geometric property of rod-like molecules. Biomed Mater Eng. 2009;19(1):3-9.

97. Yannas IV, Burke JF, Orgill DP, Skrabut EM. Wound tissue can utilize a polymeric template to synthesize a functional extension of skin. Science. 1982;215(4529):174-176.

98. Vasita R, Katti DS. Nanofibers and their applications in tissue engineering. Int J Nanomedicine. 2006;1(1):15-30.

99. Oh S, Brammer KS, Li YS, et al. Stem cell fate dictated solely by altered nanotube dimension. Proc Natl Acad Sci U S A. 2009;106(7): 2130-2135.

100. Namgung S, Kim T, Baik KY, Lee M, Nam JM, Hong S. Fibronectincarbon-nanotube hybrid nanostructures for controlled cell growth. Small. 2010;7(1):56-61.

101. Cao Y, Zhou YM, Shan Y, Ju HX, Xue XJ. Preparation and characterization of grafted collagen multiwalled carbon nanotubes composites. J Nanosci Nanotechnol. 2007;7:447-451.

102. Baughman RH, Cui C, Zakhidov AA, et al. Carbon nanotube actuators. Science. 1999;284(5418):1340-1344. 
103. Dalton AB, Collins S, Munoz E, et al. Super-tough carbon-nanotube fibres. Nature. 2003;423(6941):703-703.

104. Yu MF, Files BS, Arepalli S, Ruoff RS. Tensile loading of ropes of single wall carbon nanotubes and their mechanical properties. Phys Rev Lett. 2000;84(24):5552-5555.

105. Saito N, Usui Y, Aoki K, et al. Carbon nanotubes for biomaterials in contact with bone. Curr Med Chem. 2008;15(5):523-527.

106. Halvorsen YD, Franklin D, Bond AL, et al. Extracellular matrix mineralization and osteoblast gene expression by human adipose tissue-derived stromal cells. Tissue Eng. 2001;7(6):729-741.

107. Rawadi G, Vayssière B, Dunn F, Baron R, Roman-Roman S. BMP-2 controls alkaline phosphatase expression and osteoblast mineralization by a Wnt autocrine loop. J Bone Miner Res. 2003;18(10): 1842-1853.

108. Venugopal J, Low S, Choon AT, Kumar TSS, Ramakrishna S. Mineralization of osteoblasts with electrospun collagen/hydroxyapatite nanofibers. J Mater Sci. 2008;19:2039-2046.

109. Veetil JV, Ye K. Tailored carbon nanotubes for tissue engineering applications. Biotechnol Prog. 2009;25(3):709-721.

110. Saito N, Usui Y, Aoki K, et al. Carbon nanotubes: biomaterial applications. Chem Soc Rev. 2009;38(7):1897-1903.

111. Zhao B, Hu H, Mandal SK, Haddon RC. A bone mimic based on the self-assembly of hydroxyapatite on chemically functionalized single-walled carbon nanotubes. Chem Mater. 2005;17(12): 3235-3241.

112. Zanello LP, Zhao B, Hu H, Haddon RC. Bone cell proliferation on carbon nanotubes. Nano Lett. 2006;6(3):562-567.

113. Khang D, Kim SY, Liu-Snyder P, Palmore GT, Durbin SM, Webster TJ. Enhanced fibronectin adsorption on carbon nanotube/poly(carbonate) urethane: independent role of surface nano-roughness and associated surface energy. Biomaterials. 2007;28(32): 4756-4768.

114. Meng J, Song L, Meng J, et al. Using single-walled carbon nanotubes nonwoven films as scaffolds to enhance long-term cell proliferation in vitro. J Biomed Mater Res A. 2006;79A(2):298-306.

115. Watari F, Takashi N, Yokoyama A, et al. Material nanosizing effect on living organisms: non-specific, biointeractive, physical size effects. $J$ $R$ Soc Interface. 2009;6(Suppl 3):S371-S388.

116. Jell G, Verdejo R, Safinia L, Shaffer MSP, Stevens MM, Bismarck A. Carbon nanotube-enhanced polyurethane scaffolds fabricated by thermally induced phase separation. J Mater Chem. 2008;18(16):1865-1872.

117. Sirivisoot S, Yao C, Xiao X, Sheldon BW, Webster TJ. Greater osteoblast functions on multiwalled carbon nanotubes grown from anodized nanotubular titanium for orthopedic applications. Nanotechnology. 2007;18:365102.

118. Narita N, Kobayashi Y, Nakamura H, et al. Multiwalled carbon nanotubes specifically inhibit osteoclast differentiation and function. Nano Lett. 2009;9(4):1406-1413.

119. Oh S, Daraio C, Chen LH, Pisanic TR, Fiñones RR, Jin S. Significantly accelerated osteoblast cell growth on aligned $\mathrm{TiO}_{2}$ nanotubes. J Biomed Mater Res. 2006;78(1):97-103.

120. Wang W, Watari F, Omori M, et al. Mechanical properties and biological behavior of carbon nanotube/polycarbosilane composites for implant materials. J Biomed Mater Res B Appl Biomater. 2007;82(1):223-230.

121. Saito N, Okada T, Horiuchi H, et al. A biodegradable polymer as a cytokine delivery system for inducing bone formation. Nat Biotechnol. 2001;19(4):332-335.

122. Wilmowsky C, Bauer S, Lutz R, et al. In vivo evaluation of anodic $\mathrm{TiO}_{2}$ nanotubes: an experimental study in the pig. $J$ Biomed Mater Res B Appl Biomater. 2009;89(1):165-171.

123. Zhang Y, Venugopal JR, El-Turki A, Ramakrishna S, Su B, Lim CT. Electrospun biomimetic nanocomposite nanofibers of hydroxyapatite/chitosan for bone tissue engineering. Biomaterials. 2008;29(32):4314-4322.
124. SillTJ, von Recum HA. Electrospinning: applications in drug delivery and tissue engineering. Biomaterials. 2008;29(13):1989-2006.

125. Kwon OH, Lee IS, Ko YG, et al. Electrospinning of microbial polyester for cell culture. Biomed Mater. 2007;2(1):S52-S58.

126. Fujihara K, Kotaki M, Ramakrishna S. Guided bone regeneration membrane made of polycaprolactone/calcium carbonate composite nano-fibers. Biomaterials. 2005;26(19):4139-4147.

127. Zhang D, Wei S, Kaila C, et al. Carbon-stabilized iron nanoparticles for environmental remediation. Nanoscale. 2010;2(6):917-919.

128. Mazinani S, Ajji A, Dubois C. Morphology, structure and properties of conductive PS/CNT nanocomposite electrospun mat. Polymer. 2009;50(14):3329-3342.

129. Shao SJ, Zhou SB, Li L, et al. Osteoblast function on electrically conductive electrospun PLA/MWCNTs nanofibers. Biomaterials. 2011;32(11):2821-2833.

130. Schmidt CE, Shastri VR, Vacanti JP, Langer R. Stimulation of neurite outgrowth using an electrically conducting polymer. Proc Natl Acad Sci U SA. 1997;94(17):8948-8953.

131. Brown MJ, Loew LM. Electric field-directed fibroblast locomotion involves cell surface molecular reorganization and is calcium independent. J Cell Biol. 1994;127(1):117-128.

132. Tonelli FM, Santos AK, Gomes DA, et al. Stem cells and calcium signaling. Adv Exp Med Biol. 2012;740:891-916.

133. Resende RR, Adhikari A. Cholinergic receptor pathways involved in apoptosis, cell proliferation and neuronal differentiation. Cell Commun Signal. 2009;7:20.

134. Tutak W, Park KH, Vasilov A, et al. Toxicity induced enhanced extracellular matrix production in osteoblastic cells cultured on single-walled carbon nanotube networks. Nanotechnology. 2009;20(25):255101.

135. Verdejo R, Jell G, Safinia L, Bismarck A, Stevens MM, Shaffer MS. Reactive polyurethane carbon nanotube foams and their interactions with osteoblasts. J Biomed Mater Res A. 2009;88(1):65-73.

136. Raja PM, Connolley J, Ganesan GP, et al. Impact of carbon nanotube exposure, dosage and aggregation on smooth muscle cells. Toxicol Lett. 2007;169(1):51-63.

137. Garibaldi S, Brunelli C, Bavastrello V, Ghigliotti G, Nicolini C. Carbon nanotube biocompatibility with cardiac muscle cells. Nanotechnology. 2006;17(2):391-397.

138. Helfenstein M, Miragoli M, Rohr S, et al. Effects of combustionderived ultrafine particles and manufactured nanoparticles on heart cells in vitro. Toxicology. 2008;253(1-3):70-78.

139. Fung AO, Tsiokos C, Paydar O, et al. Electrochemical properties and myocyte interaction of carbon nanotube microelectrodes. Nano Lett. 2010;10(11):4321-4327.

140. McKeon-Fischer KD, Flagg DH, Freeman JW. Coaxial electrospun poly(epsilon-caprolactone), multiwalled carbon nanotubes, and polyacrylic acid/polyvinyl alcohol scaffold for skeletal muscle tissue engineering. J Biomed Mater Res A. 2011;99A(3):493-499.

141. Mu Q, Du G, Chen T, Zhang B, Yan B. Suppression of human bone morphogenetic protein signaling by carboxylated single-walled carbon nanotubes. ACS Nano. 2009;3(5):1139-1144.

142. Zhang Y, Mu Q, Zhou H, et al. Binding of carbon nanotube to BMP receptor 2 enhances cell differentiation and inhibits apoptosis via regulating bHLH transcription factors. Cell Death Dis. 2012; 3:e308.

143. Mazzatenta A, Giugliano M, Campidelli S, et al. Interfacing neurons with carbon nanotubes: electrical signal transfer and synaptic stimulation in cultured brain circuits. J Neurosci. 2007;27(26):6931-6936.

144. Mattson M, Haddon R, Rao A. Molecular functionalization of carbon nanotubes and use as substrates for neuronal growth. $J$ Mol Neurosci. 2000;14(3):175-182.

145. Lovat V, Pantarotto D, Lagostena L, et al. Carbon nanotube substrates boost neuronal electrical signaling. Nano Lett. 2005;5(6): 1107-1110.

146. Ni Y, Hu H, Malarkey EB, et al. Chemically functionalized water soluble single-walled carbon nanotubes modulate neurite outgrowth. J Nanosci Nanotechnol. 2005;5:1707-1712. 
147. Gabay T, Jakobs E, Ben-Jacob E, Hanein Y. Engineered selforganization of neural networks using carbon nanotube clusters. Physica A. 2005;350(2-4):611-621.

148. Matsumoto K, Sato C, Naka Y, Kitazawa A, Whitby RLD, Shimizu N. Neurite outgrowths of neurons with neurotrophin-coated carbon nanotubes. J Biosci Bioeng. 2007;103(3):216-220.

149. Fabbro A, Villari A, Laishram J, et al. Spinal cord explants use carbon nanotube interfaces to enhance neurite outgrowth and to fortify synaptic inputs. ACS Nano. 2012;6(3):2041-2055.

150. Cellot G, Cilia E, Cipollone S, et al. Carbon nanotubes might improve neuronal performance by favouring electrical shortcuts. Nat Nanotechnol. 2009;4(2):126-133.

151. Cellot G, Toma FM, Varley ZK, et al. Carbon nanotube scaffolds tune synaptic strength in cultured neural circuits: novel frontiers in nanomaterial-tissue interactions. J Neurosci. 2011;31(36):12945-12953.

152. Place ES, Evans ND, Stevens MM. Complexity in biomaterials for tissue engineering. Nat Mater. 2009;8(6):457-470.

153. Chao TI, Xiang S, Chen CS, et al. Carbon nanotubes promote neuron differentiation from human embryonic stem cells. Biochem Biophys Res Commun. 2009;384(4):426-430.

154. Bardi G, Tognini P, Ciofani G, Raffa V, Costa M, Pizzorusso T. Pluronic-coated carbon nanotubes do not induce degeneration of cortical neurons in vivo and in vitro. Nanomedicine. 2009;5(1): 96-104.

155. Shein M, Greenbaum A, Gabay T, et al. Engineered neuronal circuits shaped and interfaced with carbon nanotube microelectrode arrays. Biomed Microdevices. 2009;11(2):495-501.

156. Malarkey EB, Reyes RC, Zhao B, Haddon RC, Parpura V. Water soluble single-walled carbon nanotubes inhibit stimulated endocytosis in neurons. Nano Lett. 2008;8(10):3538-3542.

157. Kam NWS, Jan E, Kotov NA. Electrical stimulation of neural stem cells mediated by humanized carbon nanotube composite made with extracellular matrix protein. Nano Lett. 2009;9(1):273-278.

158. Lewitus DY, Landers J, Branch JR, et al. Biohybrid carbon nanotube/ agarose fibers for neural tissue engineering. Adv Funct Mater. 2011;21(14):2624-2632.

159. Tonelli FMP, Santos AK, Silva SL, Gomes KN, Ladeira LO, Resende RR. Stem cells and calcium signaling. In: Islam MS, editor. Calcium Signaling (Advances in Experimental Medicine and Biology). Vol 740. Dordrecht: Springer; 2012.

160. Lindsey S, Papoutsakis ET. The importance of physiologically inspired physicochemical parameters on hematopoietic stem-cell maintenance and lineage-specific differentiation in ex vivo cultures. In: Stachowiak MK, Tzanakakis ES, editors. Stem Cells: Mechanisms and Technologies. World Scientific Publishing and Imperial College Press; 2011.

161. Bianco P, Robey PG. Stem cells in tissue engineering. Nature. 2001;414:118-121.

162. Holy J, Perkins E, Yu X. Differentiation of pluripotent stem cells on multiwalled carbon nanotubes. Conf Proc IEEE Eng Med Biol Soc. 2009;2009:6022-6025.

163. McCullen SD, Stevens DR, Roberts WA, et al. Characterization of electrospun nanocomposite scaffolds and biocompatibility with adipose-derived human mesenchymal stem cells. Int J Nanomedicine. 2007;2(2):253-263.

164. Kam NWS, Jan E, Kotov NA. Electrical stimulation of neural stem cells mediated by humanized carbon nanotube composite made with extracellular matrix protein. Nano Lett. 2009;9(1):273-278.

165. Tay CY, Gu HG, Leong WS, et al. Cellular behavior of human mesenchymal stem cells cultured on single-walled carbon nanotube film. Carbon. 2010;48(4):1095-1104.

166. Namgung S, Baik KY, Park J, Hong S. Controlling the growth and differentiation of human mesenchymal stem cells by the arrangement of individual carbon nanotubes. ACS Nano. 2011;5(9): 7383-7390.

167. Holy J, Perkins E, Yu X. Adhesion, proliferation and differentiation of pluripotent stem cells on multi-walled carbon nanotubes. IET Nanobiotechnol. 2011;5(2):41-46.
168. Li WJ, Tuli R, Okafor C, et al. A three-dimensional nanofibrous scaffold for cartilage tissue engineering using human mesenchymal stem cells. Biomaterials. 2005;26:599-609.

169. Siddappa R, Martens A, Doorn J, et al. cAMP/PKA pathway activation in human mesenchymal stem cells in vitro results in robust bone formation in vivo. Proc Natl Acad Sci USA. 2008;105: 7281-7286.

170. Levenberg S, Huang NF, Lavik E, Rogers AB, Itskovitz-Eldor J, Langer R. Differentiation of human embryonic stem cells on three-dimensional polymer scaffolds. Proc Natl Acad Sci U S A. 2003;100(22):12741-12746.

171. Willerth SM, Arendas KJ, Gottlieb DI, Sakiyama-Elbert SE. Optimization of fibrin scaffolds for differentiation of murine embryonic stem cells into neural lineage cells. Biomaterials. 2006; 27(36):5990-6003.

172. Gul H, Lu W, Xu P, Xing J, Chen J. Magnetic carbon nanotube labelling for haematopoietic stem/progenitor cell tracking. Nanotechnology. 2010;21:19-28.

173. Reves BT, Jennings JA, Bumgardner JD, Haggard WO. Preparation and functional assessment of composite chitosan-nano-hydroxyapatite scaffolds for bone regeneration. J Funct Biomater. 2012;3(1): 114-130.

174. Karimov KS, Saleem M, Karieva ZM, Khan A, Qasuria TA, Mateen A. A carbon nanotube-based pressure sensor. Phys Scr. 2011;83(6): 56-62.

175. Marschilok A, Lee CY, Subramanian A, Takeuchi KJ, Takeuchi ES. Carbon nanotube substrate electrodes for lightweight, long-life rechargeable batteries. Energy Environ Sci. 2011;4:2943-2951.

176. Polizu S, Savadogo O, Poulin P, Yahia L. Applications of carbon nanotubes-based biomaterials in biomedical nanotechnology. J Nanosci Nanotechnol. 2006;6(7):1883-1904.

177. Mazzatenta A, Giugliano M, Campidelli S, et al. Interfacing neurons with carbon nanotubes: electrical signal transfer and synaptic stimulation in cultured brain circuits. J Neurosci. 2007;27(26): 6931-6936.

178. Vasita R, Katti DS. Nanofibers and their applications in tissue engineering. Int J Nanomedicine. 2006;1(1):15-30.

179. Verdejo R, Jell G, Safinia L, Bismarck A, Stevens MM, Shaffer MS. Reactive polyurethane carbon nanotube foams and their interactions with osteoblasts. J Biomed Mater Res A. 2009;88(1):65-73.

180. Li X, Liu H, Niu X, et al. The use of carbon nanotubes to induce osteogenic differentiation of human adipose-derived MSCs in vitro and ectopic bone formation in vivo. Biomaterials. 2012;33(19): 4818-4827.

181. Oh S, Daraio C, Chen LH, Pisanic TR, Fiñones RR, Jin S. Significantly accelerated osteoblast cell growth on aligned $\mathrm{TiO}_{2}$ nanotubes. J Biomed Mater Res. 2006;78(1):97-103.

182. Mattson MP, Haddon RC, Rao AM. Molecular functionalization of carbon nanotubes and use as substrates for neuronal growth. $J \mathrm{Mol}$ Neurosci. 2000;14(3):175-182.

183. Lovat V, Pantarotto D, Lagostena L, et al. Carbon nanotube substrates boost neuronal electrical signaling. Nano Lett. 2005;5(6): 1107-1110.

184. Narita N, Kobayashi Y, Nakamura H, et al. Multiwalled carbon nanotubes specifically inhibit osteoclast differentiation and function. Nano Lett. 2009;9(4):1406-1413.

185. Chao TI, Xiang S, Chen CS, et al. Carbon nanotubes promote neuron differentiation from human embryonic stem cells. Biochem Biophys Res Commun. 2009;384(4):426-430.

186. Kam NW, Jan E, Kotov NA. Electrical stimulation of neural stem cells mediated by humanized carbon nanotube composite made with extracellular matrix protein. Nano Lett. 2009;9(1):273-278.

187. Li WJ, Tuli R, Okafor C, et al. A three-dimensional nanofibrous scaffold for cartilage tissue engineering using human mesenchymal stem cells. Biomaterials. 2005;26(6):599-609. 
188. Kim JA, Jang EY, Kang TJ, Yoon S, Ovalle-Robles R, Rhee WJ, Kim T, Baughman RH, Kim YH, Park TH. Regulation of morphogenesis and neural differentiation of human mesenchymal stem cells using carbon nanotube sheets. Integr Biol (Camb). 2012;4(6):587-594.

189. Park SY, Choi DS, Jin HJ, Park J, Byun KE, Lee KB, Hong S. Polarization-controlled differentiation of human neural stem cells using synergistic cues of carbon nanotube network patterns, ACS Nano. 2011;5(6): 4704-4711.
190. Chen C-S, Soni S, Le C, Biasca M, Farr E, Chen EYT, Chin WC. Human stem cell neuronal differentiation on silk-carbon nanotube composite. Nanoscale Res Lett. 2012;7(1): 126-130.
International Journal of Nanomedicine

\section{Publish your work in this journal}

The International Journal of Nanomedicine is an international, peerreviewed journal focusing on the application of nanotechnology in diagnostics, therapeutics, and drug delivery systems throughout the biomedical field. This journal is indexed on PubMed Central, MedLine, CAS, SciSearch ${ }^{\circledR}$, Current Contents ${ }^{\circledR} /$ Clinical Medicine,

\section{Dovepress}

Journal Citation Reports/Science Edition, EMBase, Scopus and the Elsevier Bibliographic databases. The manuscript management system is completely online and includes a very quick and fair peer-review system, which is all easy to use. Visit http://www.dovepress.com/ testimonials.php to read real quotes from published authors.

Submit your manuscript here: http://www.dovepress.com/international-journal-of-nanomedicine-journal 